\title{
Sürdürülebilir Sosyal Güvenlik Sistemi İçin Mali Kural Önerisi*
}

\author{
Volkan YURDADOĞ $\breve{G}^{* *}$ Haşim AKÇA ${ }^{* * *}$ Oğuzhan BOZATLI**** \\ $\ddot{O} Z$
}

Bu çalışmanın temel amacı; Türk Sosyal Güvenlik Sistemini sürdürülebilir ve etkin bir temele oturtmak için mali kural önerisinde bulunmaktır. Türkçe literatürde mali kural ile ilgili birçok çalışma olmakla beraber sosyal güvenlik sisteminde mali kurala yönelik herhangi bir çalışmaya rastlanmamıştır. Türkçe dışındaki literatür incelendiğinde ise özellikle Avrupa Birliği ülkelerinin 1992 yılından bu yana sosyal güvenlik sistemi için mali kural uyguladıkları gözlemlenmiştir. Bu çalışmada, Avrupa Birliği örneklerinden de hareketle Türk Sosyal Güvenlik Sistemi için mali kural önerisinde bulunulmuştur. Ayrıca ulusal yazında Anayasanın 65.maddesine genellikle hukuksal açıdan yaklaşıldı̆̆ ve söz konusu maddenin Türk Sosyal Güvenlik Sistemine yönelik mali ve iktisadi etkilerinin ihmal edildiği tespit edilerek önerilen mali kural çerçevesi ile uyumlu olarak yeni bir yorum önerisinde bulunulmuştur. Analiz sonucunda Türk Sosyal Güvenlik Sisteminin sürdürülemez düzeyde olan açıklarını kontrol altına almak adına önerilen mali kural çerçevesinin kesin bir çözüm olmadı̆̆ ancak bu çerçeve ile birlikte önerilen kurumsal düzenlemelerin yapılmasının kayda değer şekilde iyileşmeler sağlayacă̆l vurgulanmıştır.

Anahtar Kelimeler: Türk Sosyal Güvenlik Sistemi, Anayasa ve 65.madde, Mali Kural, Sosyal Güvenlik Açıkları

JEL Sinıflandırması: H55, H60

\section{Fiscal Rule Proposal For Sustainable Social Security System}

\begin{abstract}
The main purpose of this study is to propose a fiscal rule to put the Turkish Social Security System on a sustainable and effective basis. Although there are many studies on the fiscal rule on the studies in Turkish, any available study on the fiscal rule has been found in the social security system. As the studies aside from the Turkish is examined, it has been observed that the European Union countries applied fiscal rules for social security system since 1992. In this study, a fiscal rule was proposed for the Turkish Social Security System in line with the European Union case. In addition, it was determined that the 65th article of the Constitution was generally approached legally in the national literature and that the fiscal and economic impacts of the considered article on the Turkish Social Security System were neglected and a new interpretation was proposed in accordance with the proposed fiscal rule framework. As a result of the analysis, it was emphasized that the proposed fiscal rule framework for controlling the unsustainable deficits of the Turkish Social Security system is not a definite solution, but that the proposed institutional arrangements with this framework would provide significant improvements.
\end{abstract}

Keywords: Turkish Social Security System, Constitution and 65.Article, Fiscal Rule, Social Security Deficits

JEL Classification: $H 55, H 60$

\footnotetext{
* Bu çalışma, 7-8 Aralık 2018 tarihleri arasında Antalya, Türkiye'de düzenlenen "2. Uluslararası Türk Dünyası Eğitim Bilimleri ve Sosyal Bilimler Kongresi” nde sunulan bildirinin gözden geçirilmiş, genişletilmiş ve yeniden düzenlenmiş halidir.

*** Doç. Dr., Çukurova Üniversitesi İ̈BF Maliye Bölümü, Adana, vyurdadog@cu.edu.tr

**** Doç. Dr., Çukurova Üniversitesi İIBF Maliye Bölümü, Adana, hakca@ cu.edu.tr

${ }^{* * * *}$ Çukurova Üniversitesi, Sosyal Bilimler Enstitüsü,Maliye Anabilim Dalı, Adana,oguzhanbozatli@gmail.com
}

(Makale Gönderim Tarihi: 22.03.2019 / Yayına Kabul Tarihi:27.07.2019) 


\section{GİRIŞ}

İnsanoğlunun geleceğini teminat altına alması fikrinden doğan sosyal güvenlik, gerçekleşmesi muhtemel olumsuzluklara veya risklere karşı önlemler alma çabasının ürünüdür. Modern anlamda sosyal güvenlik, 19. ve 20. yüzyılda Kita Avrupası ülkelerinde yaşanan politik, sosyal ve ekonomik çatışmaların bir ürünü olarak bugünkü konumuna gelmiştir. Özellikle Kıta Avrupası ülkelerinde ortaya çıkmasının ardında yatan temel sebepler ise sanayileşmesini tamamlayan bu ülkelerde ortalama yaşam sürelerinin düşüklüğü, iş kazalarındaki artış, yoksulluğun artması ve sağlık hizmetine duyulan ihtiyacın artmasıdır. Avrupa ülkelerinde bu gelişmeler yaşanırken Osmanlı Devleti'nde ise bugünkü anlamında olmasa da bir nevi sosyal güvenlik fonksiyonu gören Ahilik, lonca ve vakıf gibi geleneksel kurumlar vardı. Cumhuriyetin ilanından 1961 Anayasasına kadar olan dönemde ise oldukça dar kapsamlı olsa da sosyal güvenlik kanunlarının çıkarıldığı gözlemlenmektedir. Sosyal güvenlik hakkı Türkiye'de ilk olarak 1961 Anayasası ile kabul edilmiştir. Sosyal güvenlik hakkının kapsamı, 1982 Anayasasında genişletilmekle beraber devletin bu hakkı sağlarken sınırlarının olduğu belirtilmiştir.

Çalışmada değinecek konulardan ilki Hukuk ve Sosyal güvenlik kavramlarının birbiri ile olan etkileşimi sonucu yapılanan Sosyal Güvenlik Kurumuyla ilgilidir. Esasen asıl üzerinde durulan Anayasanın 65. Maddesi olup, kimi hukukçuların olumsuz kimilerinin ise olumlu olarak yorumlasalar da sosyal güvenlik harcamaları hiç azalmamış aksine hep artarak bütçenin, dolayısıyla devletin veya hükümetlerin üzerinde yük olmuştur. Bu noktada sosyal güvenlik açıklarının nedenleri ve etkileri üzerinde durulmuş, konu üzerinde araştırmalarla ilgili literatür taraması verilerek genel anlamda bu açıkların nedenleri ve yansımaları anlatılmaya çalışılmıştır. Akabinde mali kuralın tarihsel, felsefi ve teorik kısmına değinilmiştir. Ardından konumuzla ilgisi açısından sosyal güvenlikle ilgili olarak mali kural uygulayan ülkeler örneklendirilmiştir. Bahsi geçen teori ve uygulamalardan hareketle bu çalışmanın amacı ise Türk Sosyal Güvenlik Sisteminin etkin ve sürdürülebilir bir yapıya kavuşturmak amacıyla mali kural önerisi sunmaktır.

\section{ANAYASA, KANUN VE SOSYAL GÜVENLIIK}

Bugünkü manasını tam olarak karşılamasa da tarihin her evresinde, olası tehlikelere karşı korunma ihtiyacı her toplum ve devlette var olmuştur. İnsan Hakları Evrensel Bildirisi'nin 22. Maddesinde temel bir insan hakk1 olarak gösterilen ve bu hakkın sağlanmasında devlete önemli bir pay biçen sosyal güvenliğin en temel amac1, bireylerin karşı karşıya kaldığ1 sosyal riskler karşısında güvence sağlamaktır. Ortak bir tanımının olmadığı sosyal güvenlik ile ilgili olarak gerek teorik gerekse de uygulama yöntemleri ülkeden ülkeye değişmektedir. Hangi risklerin sosyal güvenlik kapsamı içerisinde yer alıp almayacağı her ülkenin iktisadi, siyasi ve sosyal yapısı ile yakından ilişkilidir. Ancak bu durum sistemler arasında ortak noktaların olmayacağı anlamına gelmemelidir (Yurdadoğ, 2017a). 
Türk Hukukunda sosyal güvenlik hakk1, ilk olarak 1961 Anayasası'nın 48. Maddesinde "Herkes sosyal güvenlik hakkına sahiptir. Bu hakkı sağlamak için sosyal sigortalar ve sosyal yardım teşkilatı kurma ve kurdurmak devletin ödevlerindendir" ibaresi ile anayasal zeminde düzenlenmiştir. 1982 Anayasası'nda ise 60. Maddede "Herkes, sosyal güvenlik hakkına sahiptir. Devlet, bu güvenliği sağlayacak gerekli tedbirleri alır ve teşkilatı kurar." hükmüne yer verilerek anayasal hak tanımlanmıştır (Fırat, 2016: 319; Karabulut, 2016: 199).

2006 yılında 5502 say1lı Sosyal Güvenlik Kurumu (SGK) Kanunu'nun yürürlüğe girmesi ile birlikte Türkiye'de Emekli Sandığı, Sosyal Sigortalar Kurumu ve Bağ-Kur'dan oluşan dağınık bir yapıdaki sosyal güvenlik sistemi tek çatı altında birleştirilmiştir. 5502 sayılı kanun, dağınık halde bulunan sistemi SGK çatısı altında bir araya toplarken, aynı zamanda farklı sosyal sigorta rejimleri 5510 sayılı kanunla beraber bir araya getirilmiştir. Yapılan bu düzenlemeler neticesinde Türk Sosyal Güvenlik Sistemi iki temel yapı olarak SGK ve Türkiye İş Kurumu şeklinde oluşturulmuştur. Tamamlayıcı unsur olarak ise Bireysel Emeklilik Sistemi kurulmuştur. Bu düzenlemeler ile prim ödeyenlerin hak ve yükümlülüklerinin eşitlendiği, mali olarak sürdürülebilir bir sistemin kurulması hedeflenmiştir (Fırat, 2016: 319; Cural, 2016: 695). Dış denetim açısından 5018 sayılı Kamu Mali Yönetimi Kontrol Kanunu (KMYKK) 41. Maddesine göre, idari faaliyet raporlarının Sayıştay ve Cumhurbaşkanlığı'na gönderilmesi ve incelenmesi, iç denetim noktasında ise Rehberlik ve Teftiş Başkanlığı ile İç Denetim Birimi Başkanlığı yoluyla gerçekleştirilmektedir.

\section{ANAYASANIN 65. MADDESİ VE SOSYAL GÜVENLIIK}

Sosyal güvenlik hakk1 1982 Anayasasının 65. Maddesinde düzenlenmiştir. 2001 yılındaki değişiklik öncesi 1982 Anayasası'nın ilk halinde 65. Madde şöyledir: "Devlet, sosyal ve ekonomik alanlarda Anayasa ile belirlenen görevlerini, ekonomik istikrarın korunmasını gözeterek, malî kaynaklarının yeterliliği ölçüsünde yerine getirilir." 2001 yılında yapılan değişiklikle söz konusu madde şöyle değiştirilmiş̧ir: "Devlet, sosyal ve ekonomik alanlarda Anayasa ile belirlenen görevlerini, bu görevlerin amaçlarına uygun öncelikleri gözeterek mali kaynaklarının yeterliliği ölçüsünde yerine getirir." Bahsi geçen Anayasa maddesindeki değişikle, devletin ekonomik istikrarın korunmasın gözetmesine yönelik ibare kaldırılarak yerine amaçlarına uygun önceliklerin gözetilmesi ibaresi eklenmiştir.

Anayasa Hukuku ya da sosyal hak kitaplarının birçoğunda, Anayasanın 65. Maddesi gereği kadar değerlendirilmemiştir. Söz konusu maddenin getirdiği değişiklikler ve sınırlamalar maddenin ifade edilmesinin ötesine geçmemiş ve detaylı olarak tartışılmamıştır. Bu eksikliğin giderilmesi adına Anayasanın 65 . Maddesi ile ilgili yapılan yorumların literatür taraması verilmiştir:

Gözler'e göre, Anayasanın 65. Maddesiyle ilgili 2001 yılındaki değişiklik yerinde değildir. Zira Anayasanın 65. Maddesindeki bu değişiklik devletin ekonomik istikrarı göz ardı ederek vatandaşların sosyal haklarını sağlamak adına harcamalar yapacağını ifade etmektedir. Bu durum gerek değişikliğin yapıldığı 
2001 yılındaki kriz ortamında gerekse de mevcut dönemde her zaman için ihtiyaç duyulan ekonomik istikrarın göz ardı edilmesine kapı aralayabilir. Anayasanın 65. Maddesi aynı zamanda realiteyle de uyuşmamaktadır. Ayrıca böyle bir madde olmasa dahi devlet, vatandaşların ekonomik ve sosyal haklarını ancak mali kaynaklarının yeterliliği ölçüsünde gerçekleştirecektir. Doğal olarak Gözler, söz konusu maddede yapılacak değişikliklerin hukuki bir sonuç doğurmayacağını dolayısıyla hukuk âleminde değişen bir şeyin olmayacağını ifade etmektedir (Gözler, 2011: 37).

Özveri (2011: 413)'ye göre, Anayasanın değişen 65. Maddesi ile beraber devletin sorumluluğu kesinlikle sona ermemektedir. Bilakis devletin yaptığ 1 veya yapacağı tercihler hem politik hem de hukuki sonuçlar doğurur. Söz konusu maddede geçen amaçlarına uygun öncelikler yalnızca politik olarak değil hukuki olarak da kanitlanmaya muhtaçtır.

Tanör ve Yüzbaşığlu (2004:178)'na göre, “mali kaynakların yeterliliği ölçüsü" yerinde bir düzenlemedir. Zira aksi durumda hareketsizlik veya yeterli sosyal katkının gerçekleştirilmemesi neticesinde sürekli bir şekilde anayasanın ihlal edildiği yönünde söylemler rahatsızlık oluşturabilir. Ancak bu hüküm anayasa ile belirlenmiş sosyal hakların, devlet organları ve iktidarlar tarafından görmezden gelinebileceği bir mazeret olarak da öne sürülebilir.

Özbudun (2014: 154-155)'a göre, söz konusu anayasa maddesi, direkt olarak uygulanabilir bir hukuk kuralından ziyade yasama erkine politik nitelikte talimatlar veren ya da rehberlik eden program hükmü niteliğindedir.

Taşkent (1992), Anayasanın 73. Maddesine atfen devletin adil bir vergi politikası izlemediğini, verginin ağılıklı olarak ücretli kesimden tahsil edildiğini, bu koşullar altında devletin; mali imkânlarının sınırlı olduğu görüşüne itibar etmenin sosyal adaletten bahsetmeyi anlamsız kılacağ bulunmaktadır. Taşkent'e göre devletimizin mali imkânları bu kadar demek hiçbir şekilde sosyal adaletle bağdaşmamaktadır. Orhan Aldıkaçtı tarafindan ise, 65. Maddenin sosyal haklara inanmayan iktidarlar için alan yarattığ 1 öne sürülmektedir. Bununla beraber maddenin oldukça esnek bir yapıya sahip olduğunu belirterek, söz konusu maddenin anayasanın uygulanmasından ziyade iktidarda olanların uygulayacakları programlara öncelik veren bir zihniyetle yazıldığı ifade edilmektedir (Akt. Özveri, 2011).

Aslan (2009), 65. Madde ile getirilen sinırlama konusunda iki kriterli bir değerlendirme sunmaktadır. İlk kriterde "devletin görevlerinin amaçlarına uygun öncelikleri gözetmesi" hususunu değerlendirerek yorum yapmaktadır. Amaç ve ödevlerin paralel gelişim gösterdiğini ifade eden Aslan devletin, ödevleri ekseninde amaçlar edinmesi gerektiğini ifade etmektedir. Bunun neticesinde görevlerin amaçlara uygunluğunun teşhis ve tespitinde sorunsallar ortaya çıkmaktadır. Bu sorunsalları ise, haklar çatışması olarak belirten Aslan, Anayasanın 5. Maddesinde belirtilen sosyal hukuk devleti ve adalet ilkeleri ile aşılacağını ifade etmektedir. İkinci kriter olarak "Devletin mali kaynaklarının yeterliliğ $i$ " hususunu değerlendirerek, bu ifadenin devletin amaç ve gayelerini tam anlamıyla ifa etmemesi üzerine bir mazeret olarak yorumlamaktadır. Aslan'a 
göre yolsuzluğun olmadığı, kaynakların etkin kullanıldığı, kalkınmanın teşvik edildiği, adil bir vergilemenin yapıldığı devlet düzeninde mali kaynakların yetersizliği söz konusu olamaz (Aslan, 2009:142-144).

Sağlam'a göre, sosyal devlet ilkesinin işletilmesi önündeki asıl engel, 1982 Anayasasının 65. Maddesinde geçen ekonomik istikrarın gözetilmesi hususudur. 1961 Anayasasında yer almayan bu ölçüt sosyal devlet ilkesini ve devlet ödevlerini göreceli bir duruma sokarak sürekli tehir edilmesini sağlamaktadır. 2001 Anayasa değişikliğinde bu hususun gözden geçirilerek sosyal devlet ilkesini işletmeme yönündeki elverişli mazeret gerekçesi giderilmiştir. 65 . Maddenin tek bir işlev olarak sosyal devlete sınır getirmek şeklinde yorumlanamayacağını ayrıca mali kaynakların yeterliliği ölçütünün realiteyi yansıtan bir hudut çizdiğini, bugüne kadar ihmal edilen asıl işlev olarak kaynakların tahsisatı ve yeterliliğini de içine alan müspet bir ölçü olduğunu ifade etmektedir (Sağlam, 2008: 755-759).

Anayasa'nın 65. Maddesini oldukça esnek bir yapıda hatta kaygan bir zemin olarak nitelendiren Kaboğlu, ilgili Anayasa maddesinin Anayasa Mahkemesi (AYM) tarafından oldukça devletçi bir şekilde yorumlandığının altını çizmektedir. 2001 yılında yapılan değişiklik öncesi ve sonrasında AYM kararlarının aynı çizgide devam ettiğini belirterek sosyal haklar lehine sağlanan anayasal gelişmenin AYM kararlarına yansımadığını belirtmektedir (Kaboğlu, 2010: 45-46).

Özveri (2011: 150) ve Algan (2006: 446-447)'ya göre, Anayasanın 90. Maddesi ekseninde düşünüldüğünde sosyal hakların uluslar arası sözleşmelerde yer almas1, söz konusu 65. Maddenin getirdiği sınırlamalara bir engel olarak değerlendirilebilir. Zira bahsi geçen 90. Madde anayasanın üstünde yer alan bir norm niteliğindedir.

Algan (2006)'ya göre, 1982 Anayasası'nın 65. maddesinin ilk halinde "ekonomik istikrarın korunması" ölçütünün 1961 Anayasası'nda yer alan "iktisadi gelişme" ölçütüne nazaran devlete, geniş bir takdir yetkisi sağladığı, dolayısıyla maddenin ilk düzenleme biçimi ile de 1961 Anayasası'nın gerisinde kalındığı açıktır. Zira ekonomik istikrarın sağlanması, iktisadi gelişmeden daha sancılı ve zaman alıcı bir süreçtir. İktisadi gelişme, ancak sağlıklı ve sürekli olduğunda bir ülkenin ekonomik istikrara kavuştuğu söylenebilir. Bu durumda 1982 Anayasası'nın 65. Maddesinin ilk şekline göre 1961 Anayasasındaki hükme nazaran daha zor bir koşula bağlanmıştır. 2001 yılında yapılan değişiklikle Anayasanın 65. Maddesinden çıkarılan ekonomik istikrar kavramı belirsizlik yarattığından olumlu bir gelişmedir. Ancak bu durum devletin bahsi geçen ödevleri yerine getirirken ekonomik istikrarı göz ard1 edeceği şeklinde yorumlanmamalıdır. Anayasanın 65. Maddesinin ikinci biçiminde ekonomik istikrar ifadesi yerine getirilen "görevin amaçlarına yönelik öncelikleri gözeterek” ifadesi oldukça isabetlidir. Bu koşul bu görevleri ifa ederken devletin etkinliği sağlamasına yardımcı olacaktır. "Mali kaynakların yeterliliği” ölçütü ise ekonomik ve sosyal haklar bakımından bir kısitlama anlamına gelmekle beraber devletin, bu haklar nedeniyle oluşan yükümlülüklerinden tamamen sıyrılma 
firsatını yakalaması şeklinde yorumlanamaz. Bu madde ile, söz konusu sosyal ve ekonomik ödevlerin devlet tarafindan ifa edilip edilmemesi meselesinden ziyade ödevlerin uygulanış derecesi mali kaynakların yeterliliğine bağlanmıştır. $\mathrm{Bu}$ durum realiteye oldukça uygundur kaldı ki, mesele aslen devletin bu ödevleri yerine getirirken sınırlı kaynaklarını nasıl paylaştıracağıdır. Bu konudaki takdir yetkisi yasama organına, uygulama yetkisi ise yürütme organına verilmiştir. Yarg1 oranlarının devletin mali kaynaklarının yeterliliğini ölçmeye kalkışması yetki aşımına girmektedir ve hukuksal sınırların zorlanarak yerindelik denetimi yapıldığı anlamına gelir. Oysa yarg1 organlarının bu alanda denetim yetkisi oldukça sinırlı bir düzeydedir (Algan, 2006: 442-446).

Temiz (2014: 183)'e göre, Anayasanın 65. Maddesi negatif haklar bakımından uygulanabilir değildir. Anayasanın gerek 56. gerek se de 17 . Maddeleri gereği devletin ekonomik ve sosyal alandaki görevlerini ifa ederken uygulayacağ 1 sınırlamalarda yaşama hakkını ortadan kaldıran düzenlemeler yapamayacaktır. Temiz anayasal düzeyde kaynak kısıtının tanınmasının devlet için bir tür mazeret firsatı doğurabileceğini vurgulamaktadır.

Atar (2002: 10)'a göre, Anayasanın 65.maddesi ile ilgili olarak 2001 yılında yapılan değişiklikle beraber "ekonomik istikrarın korunması" gibi muğlak bir tanımın yerine "amaca uygun önceliklerin" tanımının getirilmesi oldukça yerinde bir değişikliktir (Akt. Dinler, 2008: 4).

İzgi ve Gören (2002, 661)'e göre, devlete mali kaynaklarının yeterliliği ölçüsünde görev yüklenmesi, aynı zamanda ekonomik istikrarı da kapsayıcı ve koruyucu bir anlam taşıdığını ifade etmişlerdir (Akt. Dinler, 2008: 4).

Bulut (2003)'a göre, Anayasanın 65. Maddesinin ikinci biçimiyle ilgili olarak yapılan değişikliğin, Anayasanın 5. Maddesi ile belirtilen amaçlara ne ölçüde ulaşılacağının takdirini yasama ve yürütme organına bırakmaktadır. Ancak belirtilmelidir ki bu takdir hakkı, değişiklik öncesinde olduğu gibi devlete hareketsiz kalma imkânı sağlayacak kadar geniş değildir.

Çelik (2007: 8-9)'e göre, Anayasanın 65. Maddesi devletin kendisi için ödev, vatandaşlar için hak olan sosyal güvenliğin sağlanması görevini ifa ederken sosyal sigortacılığın teknik gereklerine uygun olarak bazı sinırlamalar yapma hakkı sağlamaktadır. Ancak sosyal güvenlik hakkını tamamen ortadan kaldırıcı duruma getiren müdahaleler yapma yetkisini vermemektedir. Nitekim AYM'nin 23.02.2001 tarihli, E.1999/42, K.2001/41 sayılı kararında ifade edildiği gibi, sosyal güvenlik sisteminde yapılan düzenlemelerin, hukuk güvenliğini zedelemeyecek biçimde "adil, makul ve ölçülü” olması zorunlu kılınmaktadır. Bu nedenle Cumhuriyetin temel ilkelerinden olan "sosyal hukuk devleti" ilkesini esas almadan 65. Maddeye yapilan atıf ve yorumlar son derece daraltıcı ve yanilticidir. Aynı şekilde AYM'nin 65. Maddeyi daraltıcı bir anlamla yorumlaması Çelik'e göre sosyal hukuk devleti ilkesinin ihlalidir.

Tuncay ve Ekmekçi (2016: 96)'ye göre, Anayasanın 65. Maddesinin getirdiği sınırlayıcı hüküm gerçekçidir. Ancak altı çizilmelidir ki, bu madde aynı zamanda sosyal güvenliğin gelişimi açısından oldukça sakıncalıdır.

Genel olarak değerlendirildiğinde hukukçular iki zit kutupta 
görünmektedir. Bazı hukukçular söz konusu maddenin gayet müspet yönlerini, bazı hukukçular da olumsuz yönlerini öne çıkarmaktadır. Ancak yapılan yorumlar genellikle hukuki nitelikte olup, sosyal güvenliğin mali yapısı ve mali etkileri ihmal edilmektedir. Bu noktada dikkate alınması gereken aslında daha genel ve daha kapsayıcı bir durumun varlığıdır.

Şöyle ki AYM 4046 sayılı Kanun'un geçici 15. Maddesini Anayasa'nın 48. ve 60. maddelerine aykırı bularak iptal etmiştir. Mahkeme itiraz konusu maddeyi şu gerekçelerle iptal etmiştir (Erdoğan, 2014: 206); “Anayasa'nın 60. maddesinde, devlete verilen görevin, 65. maddede belirtildiği biçimde "mali kaynaklarının yeterliliği ölçüsünde” yerine getirilebileceği açıktır. Ancak, devlet sosyal güvenliği sağlamak için, kurumsal bir yapılanmayı gerçekleştirmişse, bunu korumak ve geliştirmekle yükümlüdür. Bu doğrultuda devlete düşen görev, sosyal güvenlik kurumlarının gücünün zayıflamasına neden olabilecek düzenlemelerden kaçınmaktır (AYM, 31.01.1997, 1996/66, 1997/7). Burada altı çizilmesi gereken nokta şudur; devlete düşen asıl görev, sosyal güvenlik kurumlarının güçlü k1lınması ve kurumun zayıflamasına neden olabilecek mali ve hukuki düzenlemelerden kaçınılmasıdır. Aslında AYM'nin bu ifadesi Anayasanın 65 . Maddesinden daha kapsayıcı, açık ve yol gösterici niteliktedir. Bu ifade sadece hukuki bir yorumdan ziyade mali anlamda da bir yorumu kapsadığından kanaatimizce dikkate alınması gerekmektedir.

Hülasa her ne kadar devletin bu madde ile görevini savsakladığı söylense de en nihayetinde ekonomik istikrarın gözetilmesi de oldukça önem arz etmektedir. Zira sürdürülebilir mali sisteme sahip olamayan veya tesis edemeyen devletin uzun dönemde temel haklar diye nitelendirebileceğimiz hakları sağlayamama gibi sorunlarla karşı karşıya kalması söz konusu olabilir. Bu nedenle maddeye yalnızca hukuksal bir açıdan bakarak yapılan değerlendirmeler eksik kalmakta ve ekonomik tahlillere de önem vermemiz gerektiği oldukça önem arz etmektedir.

\section{TÜRKIYE'DE SOSYAL GÜVENLIK AÇIKLARININ NEDENLERI VE ETKILERI}

Sosyal güvenliğin hukuki düzeni incelendikten sonra şimdi de açıkların nedenleri ve mali etkileri üzerinde durulacaktır.

\section{A. Türkiye'de Sosyal Güvenlik Açıklarının Nedenleri}

Türk Sosyal Güvenlik Sisteminin en büyük sorunu kronik olarak verdiği açıklardır. Bu açıklar yapısal ve siyasi tercihlerinin ürünü olmakla beraber bütçe üzerinde ağır bir yük oluşturmaktadır. Konu üzerinde çalışan araştırmacılar, bütçenin kara deliği olarak sosyal güvenlik açıklarına işaret etmektedirler. Her yıl düzenli olarak açık veren sosyal güvenlik sistemi, Hazine tarafından bütçe transferleri yoluyla kapatılmaya çalışılmaktadır. Yapılan bütçe transferleri bütçe açıkları ve kamu kesimi borçlanma gereğini arttırmaktadır. Bu nedenle bu yapısal sorunun üzerine eğilmek birden çok mali göstergeye yönelik yapısal sorunları çözüm sağlamaya çalışmak amacını gütmektedir.

Türkiye'de sosyal güvenlik açıklarına neden olan etmenler literatür incelendiğinde, Tablo 1'e göre gelir, gider, yapısal ve son olarak politik ve sosyal 
kaynaklı olarak gruplandırılabilir.

Tablo 1. Sosyal Güvenlik Açıklarının Nedenleri

\begin{tabular}{|c|c|c|c|}
\hline Gelir Kaynakh Nedenler & Gider Kaynakh Nedenler & Yapisal Nedenler & Politik ve Sosyal Nedenler \\
\hline Prim oranlarmın yüksekliği & Sağlik sektöründeki ihmaller & Aktif/pasif oranının düşüklüğü, & $\begin{array}{c}\text { Sosyal güvenlik ahlakının } \\
\text { yoksunluğu }\end{array}$ \\
\hline $\begin{array}{l}\text { Gelir düzeyindeki } \\
\text { düşüklükler }\end{array}$ & $\begin{array}{c}\text { Yanlış finansman } \\
\text { yöntemlerinin uygulanmas } 1\end{array}$ & $\begin{array}{l}\text { İşgücüne katilım oranın } \\
\text { düşüklüğü }\end{array}$ & Prim aflari \\
\hline $\begin{array}{c}\text { Prim tahsilatunda yaşanan } \\
\text { sorunlar }\end{array}$ & Demografik yapıdaki değişim & $\begin{array}{c}\text { Fonlarm verimli ve etkin } \\
\text { kullanilmamas } 1\end{array}$ & $\begin{array}{c}\text { Kurumun politik } \\
\text { müdahalelere maruz kalmas1 }\end{array}$ \\
\hline $\begin{array}{l}\text { Yanlış finansman } \\
\text { yöntemlerinin uygulanması }\end{array}$ & & $\begin{array}{c}\text { Norm ve standart birliğinin } \\
\text { olmamas } 1\end{array}$ & Kayıt dişılik \\
\hline $\begin{array}{l}\text { İşücüne katilım oranın } \\
\text { düşüklüğü }\end{array}$ & & Denetim Yetersizliği & $\begin{array}{c}\text { Kurumun özerkliğinin } \\
\text { olmamas }\end{array}$ \\
\hline Kayıt dişılik & & & Erken emeklilik uygulamalan \\
\hline Prim afları & & & Demografik yapıdaki değişim \\
\hline
\end{tabular}

Kaynak: Yıldırım (2012: 70); Erol, (2014: 47-64); Demir ve Canbay (2013: 457-458); Cural (2016: 697); Tatlı ve Göçer (2015: 89-91); Güneş ve Yakar (2004: 128); Canbay ve Demir (2013: 306-313); Akça, Ünlükaplan ve Yurdadoğ (2016: 215); Altunöz (2017: 75); Gökbunar, Uğur ve Duramaz (2016) adlı çalışmalardan derlenerek oluşturulmuştur.

Tablo 1'de görüldüğü üzere Türkiye'de sosyal güvenlik açıklarının birçok boyutu göze çarpmakta olup, birbirinden bağımsız şekilde değerlendirilmemelidir. Örneğin Sosyal Güvenlik sistemine yapılan politik müdahaleler sistemin gerek gelir yönünde gerekse de yapısal yönünde sorunlara neden olmaktadır.

Sosyal Güvenlik açıklarının nedenlerini daha iyi görebilmek için nakit akım tablosu ve kurumun açıkları Tablo 2'te gösterilmiştir.

Tablo 2. Sosyal Güvenlik Kurumunun Konsolide Nakit Akım Tabloları

\begin{tabular}{|c|c|c|c|c|c|c|c|c|c|c|c|}
\hline $\begin{array}{c}\text { Gelir-Gider } \\
\text { Kalemleri }\end{array}$ & 2008 & 2009 & 2010 & 2011 & 2012 & 2013 & 2014 & 2015 & 2016 & 2017 & $\begin{array}{c}2018 \\
\text { (Ocak- } \\
\text { Mayis })\end{array}$ \\
\hline Gelirler & $\mathbf{6 7 . 2 5 7}$ & $\mathbf{7 8 . 0 7 3}$ & $\mathbf{9 5 . 2 7 3}$ & $\mathbf{1 2 4 . 4 8 0}$ & $\mathbf{1 4 2 . 9 2 9}$ & $\mathbf{1 6 3 . 0 1 4}$ & $\mathbf{1 8 4 . 3 2 9}$ & $\mathbf{2 2 0 . 1 0 2}$ & $\mathbf{2 5 5 . 8 8 0}$ & $\mathbf{2 8 8 . 5 6 0}$ & $\mathbf{3 1 2 . 2 1 1}$ \\
\hline Prim Gelirleri & 54.546 & 54.579 & 66.913 & 89.561 & 99.359 & 118.729 & 135.239 & 159.480 & 184.446 & 208.064 & 226.184 \\
\hline Diğer Gelirler & 12.711 & 23.494 & 28.360 & 34.919 & 43.569 & 44.285 & 49.090 & 60.622 & 71.434 & 80.495 & 86.026 \\
\hline Giderler & $\mathbf{9 3 . 1 5 9}$ & $\mathbf{1 0 6 . 7 7 5}$ & $\mathbf{1 2 1 . 9 9 7}$ & $\mathbf{1 4 0 . 7 1 5}$ & $\mathbf{1 6 0 . 2 2 3}$ & $\mathbf{1 8 2 . 6 8 9}$ & $\mathbf{2 0 4 . 4 0 0}$ & $\mathbf{2 3 1 . 5 4 6}$ & $\mathbf{2 7 6 . 5 3 6}$ & $\mathbf{3 1 2 . 7 3 5}$ & $\mathbf{3 4 6 . 2 5 6}$ \\
\hline Emekli Aylikları & 59.137 & $\mathbf{6 8 . 6 0 4}$ & 78.957 & 91.615 & 105.294 & 119.162 & 134.392 & 151.990 & 185.158 & 209.546 & 235.067 \\
\hline Sağlik Giderleri & 25.346 & 28.811 & 32.509 & 36.500 & 44.111 & 49.889 & 54.551 & 59.356 & 67.993 & 77.632 & 83.812 \\
\hline Diğer Giderler & $\mathbf{8 . 6 7 7}$ & $\mathbf{9 . 3 6 1}$ & 10.531 & $\mathbf{1 2 . 5 9 9}$ & 10.819 & 13.639 & 15.458 & 20.200 & 23.385 & 25.557 & 27.377 \\
\hline Açk & $\mathbf{- 2 5 . 9 0 2}$ & $\mathbf{- 2 8 . 7 0 3}$ & $\mathbf{- 2 6 . 7 2 4}$ & $\mathbf{- 1 6 . 2 3 5}$ & $\mathbf{- 1 7 . 2 9 5}$ & $\mathbf{- 1 9 . 6 7 5}$ & $\mathbf{- 2 0 . 0 7 2}$ & $\mathbf{- 1 1 . 4 4 4}$ & $\mathbf{- 2 0 . 6 5 6}$ & $\mathbf{- 2 4 . 1 7 5}$ & $\mathbf{- 3 4 . 0 4 5}$ \\
\hline
\end{tabular}

Kaynak: SGK, Aylık İstatistik Bültenleri http://www.sgk.gov.tr/wps/portal/sgk/tr/kurumsal/istatistik/ aylik istatistik bilgileri derlenerek hazırlanmıştır.

Tablo 2'ye göre SGK'nın 2008-2018 yılları itibariyle açıların her yıl düzenli olarak varlı̆̆ 1 söz konusudur. Özellikle kurumun giderleri dikkatli bir şekilde incelendiğinde emekli aylıklarının giderler içindeki ağırlığı dikkat çekmektedir. TÜİK verileri de dikkate alındığında yakın bir dönemde Türkiye'nin istihdam piyasasına yönelik nüfus tanımı olan aktif nüfusunun azalacağı ve yaşlılara yönelik harcamaların artacağ 1 düşünüldüğünde sistemin açık seviyesi artmaya devam edecektir. Özellikle böyle bir varsayım çerçevesinde hali hazırda var olan aktif/pasif oranının düşüklügü, giderler içerisindeki emekli aylıklarının büyüklüğü ve yaşlanan nüfusa yönelik artması beklenen sağlık harcamaları mali dengeleri olumsuz yönde etkileyeceği söylenebilir. 


\section{B. Türkiye'de Sosyal Güvenlik Açıklarının Etkileri}

Türk Sosyal Güvenlik Sisteminin açıkları Hazine tarafından gerçekleştirilen bütçe transferleriyle finanse edilmektedir. Bütçe transferleri; devlet katkısı, açık finansmanı, ek ödeme, faturalı ödemeler, teşvikler ve ödeme gücü bulunmayan vatandaşların genel sağlık sigortası primlerinden oluşmaktadır (Altunöz, 2017: 62; Cural, 2016: 700). Sosyal güvenlik sistemine aktarılan bütçe transferleri ve bütçe transferlerinin GSYIH' ya oranı Tablo 3'te sunulmuştur.

Tablo 3. Sosyal Güvenlik Kurumuna Yapılan Bütçe Transferleri (2008-2018)

\begin{tabular}{|c|c|c|c|}
\hline Yllar & $\begin{array}{c}\text { Sosyal Güvenlik Kurumu Bütçe } \\
\text { Transferleri }\end{array}$ & Yllhk Değişim Oranı (\%) & GSYï ya Oranı (\%) \\
\hline 2008 & 35.016 .403 & 5,9 & 3,52 \\
\hline 2009 & 52.599 .691 & 50,2 & 5,26 \\
\hline 2010 & 55.244 .258 & 5 & 4,76 \\
\hline 2011 & 52.772 .218 & $-4,5$ & 3,78 \\
\hline 2012 & 58.728 .293 & 11,3 & 3,74 \\
\hline 2013 & 71.263 .763 & 21,3 & 3,94 \\
\hline 2014 & 77.335 .890 & 8,5 & 3,78 \\
\hline 2015 & 79.038 .817 & 2,2 & 3,38 \\
\hline 2016 & 108.073 .487 & 36,7 & 4,14 \\
\hline 2017 & 128.182 .906 & 18,6 & 4,13 \\
\hline 2018 (Ocak-Mayı) & 56.451 .660 & & \\
\hline
\end{tabular}

2008-2018 (Ocak-Mayıs) yılları arasında sosyal güvenlik sistemine aktarılan bütçe transferleri ve bu transferlerin GSYİH'ya oranı Tablo 3'te gösterilmektedir. 2008 yılından bu yana sisteme aktarılan bütçe transferleri nominal değer olarak neredeyse 4 katına ulaşmışıır. Bu duruma paralel olarak ise sisteme aktarılan bütçe transferlerinin GSYİH' ya oranı da artmıştır. Söz konusu açık ve bütçe transferlerinin mali sisteme olumsuz etkileri söz konusudur. Literatürde yapılan bazı ampirik araştırmalara göre, açıkların ve transferlerin kamu maliyesine yansımaları şöyledir:

Cural (2016) ve Altunöz (2017), Türk Sosyal Güvenlik Sisteminin yapısal sorunları ve bütçe transferlerinin ekonomik etkilerini incelediği çalışmalarında sisteme aktarılan bütçe transferlerinin devlet giderlerini ve iç borç stokunu arttırdığını ve aynı zamanda devlet bütçesini de olumsuz bir şekilde etkilediğini tespit etmiştir.

Kara, Kurutkan ve Çolak (2016), sosyal güvenlik açıklarıyla makroekonomik göstergeler arasında ilişki üzerine yaptıkları çalışmada sosyal güvenlik açıları ile büyüme, iç borç ve sağlık harcamaları arasında uzun dönemde bir ilişkinin olmadığı sonucuna varmışlardır. Ayrıca sosyal güvenlik açıkları ile borçlanma arasında bir ilişki tespit edilemediğinden açıların, borçlanma dışı finansman teknikleri ile karşılandığı düşünülmektedir.

Yılmaz (2014)'a göre, sosyal güvenlik sistemine yapılan bütçe transferlerinin yüksek seviyelere ulaşması bütçe açığını ve kamu borçlanma gereğini arttıran ve ekonomiyi olumsuz yönde etkileyen bir durumdur. 
$\mathrm{Bu}$ çalışmalara göre, sisteme yapılan bütçe transferleri bütçe açıklarını arttırmakta, artan bütçe açıkları ise kamu kesimi borçlanma gereğini arttırarak kamu maliyesi göstergelerini olumsuz yönde etkilemektedir.

Artan kamu kesimi borçlanması gereğinin hangi kaynaklardan finanse edileceği oldukça önem arz etmektedir. İç kaynaklarla sağlanacaksa ülkemizde tasarruf eğilimi yüksek olan üst gelir seviyesindeki grup öne çıkmaktadır. Böyle bir borç biçimi gelir seviyesi düşük gruplar aleyhine gelir dağılımında adaleti bozucu bir etki oluşturacaktır. Söz konusu gelir dağılımındaki bozukluk kısa vadede nesil içi, orta ve uzun vadede nesiller arası bir yük oluşturma potansiyeli taşımaktadır.

Bir diğer önemli nokta ise piyasaya etkileriyle ilgilidir. Artan kamu kesimi borçlanma gereği faiz oranlarını yükselterek özel kesim yatırımlarını dışlayabilir ve dolaylı olarak prim gelirlerinden kayba uğranmasına neden olabilir. Ayrıca artan kamu borçları, şu anki göstergelere göre iyi durumda olan kamu borç seviyesini yukarı çekerek devletin mali manevra alanını daraltabilir.

\section{MALİ KURALLAR}

\section{A. Mali Kuralların Tarihsel ve Felsefi Temelleri}

İkinci Dünya Savaşı sonrası dönemde 1970'li yıllara kadar gerek iktisat gerekse de maliye yazınında ekonomi politikalarında baskın olan görüş telafi edici bütçe anlayışı ve aktif maliye politikasının ön plana çıktığı Keynezyen görüştür. Keynezyen görüş, maliye politikalarının aktif olarak kullanmanın yanında, Neo-klasik Piyasa Başarısızlığı Teorisini öne sürerek kamusal mallar, dışsallıklar ve ölçek ekonomilerinin piyasa mekanizmasının etkin bir şekilde işlemesinin önünde engel olduğunu dolayısıyla devletin ekonomik hayata müdahale etmesi gerektiğini savunmuştur. $\mathrm{Bu}$ düşüncenin pratik olarak uygulanması ve benimsenmesi devletin ekonomideki payını arttırmıştır. Keynezyen görüşün karşısında yer alan Kamu Tercihi teorisyenlerine göre ise ekonomik hayatta aktif olarak katılan müdahaleci devletin, denk bütçe ilkesinden hızla uzaklaşması sonucu ekonomi içindeki ağırlığı artacağından ekonomik ve politik yozlaşmalara yol açması kaçınılmaz olacaktır. Felsefi temellerini Sosyal Sözleşme Teorisi'nden, teorik temellerini ise Kamu Tercihi Teorisi'nden alan Anayasal İktisat Teorisi ise, politikacıların uyması gereken sınırların ve kuralların olmas1 gerektiğini savunarak devletin görev ve yetkilerinin anayasal düzeyde sınırlar çizilmesini savunmaktadır (Ünlükaplan, Yurdadoğ ve Akça, 2017: 68-69).

İradi maliye politikası uygulamalarına şiddetle karşı çıkan iktisadi ekollerin başında Anayasal İktisatçılar gelir. Mali disiplin ve mali düzenin temin edilmesi adına sayısal ve prosedürel kuralların anayasa ve/veya yasalarda yer almas1 gerektiğini savunmaktadırlar (Aktan, 2011: 7; Gökbunar, 1997). Oluşturulacak mali anayasada, seçimlerle birlikte değişen siyasi iktidarların harcamalar ve vergi oranları üzerindeki keyfi değişiklik yapabilme yetkilerini kontrol altına almak ve gelecek nesillerin üzerinde kalacak borç yükünü minimize etmeyi sağlayacak düzenlemeler önermektedirler. Ayrıca mali anayasayla, kamu harcamalarının ve vergi gelirlerinin belirli kurallara bağlanarak kontrol altına 
alınması ile beraber denk bütçe sağlanacağını öne sürmektedirler (Sakal ve Şahin, 2009: 86).

Kaynakların etkin bir şekilde kullanılması ve mali disiplinin sağlanması için siyasi iktidarların mali kurallara uyumu yasal düzenlemelerle sağlanabilir. Dolayısıyla denilebilir ki, mali kurallara uymaya zorlayan şey aslında başta anayasa olmak üzere diğer yasal düzenlemelerin varlığıdır (Ergün ve Cura, 2016: 266). Zira Kamu Tercihi veya Anayasal İktisat perspektifinden mali kuralların gündeme gelmesinde asıl sebep, kısa vadeli olarak seçilmiş siyasetçilerin kısa vadeli çıkarları ile toplumun orta ve uzun vadedeki çıkarlarının çatışmasından başka bir şey değildir. Mali kurallarla amaçlanan, bu çıkar çatışmasını minimize etmektir (Ergen, 2013: 96; Karadeniz ve Vural, 2016: 50; Karakurt ve Akdemir, 2010a: 230).

IMF'in 1985 ile 2015 yılları arasında mali kural uygulayan ülkeler hakkında yayınladığı veri seti incelendiğinde, mali kural uygulamasının Avusturalya, Japonya, Singapur, Endonezya ve Almanya'da 1985 yllinda başladığı gözlemlenmektedir. Avusturalya ve Almanya haricindeki ülkelerin hepsi yalnızca bütçe dengesi üzerine mali kural uygularken, Almanya hem harcama kuralı hem de bütçe dengesi kuralı uygulamıştır. Diğer ülkelerden farklı ve kapsamlı olarak Avusturalya ise 1985 y1lı itibari ile harcama, bütçe dengesi ve gelir kuralı olmak üzere yoğun bir şekilde mali kurala başvuran ülke olarak öne çıkmaktadır. Avrupa Birliği (AB) ülkelerine bakıldığında ise özellikle 90'l1 yıllardan sonra mali kural uygulamasına başvurdukları anlaşılmaktadır. Günümüze gelindiğinde ise 2015 y1lı itibariyle 93 ülkenin mali kural uyguladığ gözlemlenmektedir (IMF, 2016).

Mali kurallar, 1990'lı yılların başından itibaren başlayan enflasyon hedeflemesi ve gelişmiş ekonomilerde kullanılan toplam parasal büyüklükler veya döviz kuru hedeflemelerinin yerini almıştır. Mali alanda, bütçe açıklarının ve kamu borcunun azaltılması için mali kurallar, dünyanın çeşitli ülkelerinde önemli ölçüde popülerlik kazanmıştır. Tarihsel köken olarak ise mali disiplinin ne kadar önemli olduğu iki bin yıl öncesine kadar dayandırılmaktadır. M. T. Cicero'nun "bütçenin denk olmasl, hazinenin yeniden dolması ve kamu borcunun azaltılması" ifadesi bu kadim anlayışın en önemli göstergesi olarak karşımıza çıkmaktadır. Bu anlayış Klasik iktisatçılar tarafından da savunulmaya devam etmiştir. Ancak 1929 krizinin ardından klasik iktisatçılar tarafından tarafsız olması önerilen maliye politikaları, fonksiyonel maliye görüşü çerçevesinde oldukça fazla bir biçimde kullanılmıştır. Bu durum, 1980'li yıllar itibariyle ülkelerin yüksek bütçe açıkları ve yüksek seviyede kamu borçlanma seviyeleriyle karşılaşmalarına neden olmuş olup, ülkelerin makroekonomik istikrarı ve mali sürdürülebilirliği yeniden tesis etme adına bazı orta vadeli mali konsolidasyon programlarını başlatmasına zemin hazırlamıştır. Daha yakın bir zamanda ise bu eğilim artan bir şekilde maliye politikasında kurallara geçiş ile takip edilmiştir (Kopits, 2001).

Mali disiplin fikrinin kalıcı kurallara dönüşmesine yönelik resmi girişimler çeşitli ülkelerin anayasal veya yasal düzeyinde, çok yıla yayılmış üç 
aşamalı bir süreçte yaygınlaştığı söylenebilir. İlk dalga bazı federal yönetimlerde altın kuralın kabulüyle başlar. 19. Yüzyılın ortalarından beri ABD'deki çoğu eyalet ve 1920'lerden beri İsviçre'deki birkaç kanton mevcut bütçe dengesini koruma adına altın kuralı benimsemiştir. İkinci dalgada ise 2. Dünya Savaşı'ndan sonra Almanya, İtalya, Japonya ve Hollanda gibi çeşitli sanayileşmiş ülkeler gerçekleştirdikleri parasal reformları takiben hedeflenen mali istikrarı destekleyici dengeli bütçe kurallarını uygulamaya koymuşlardır. Bu kuralların çoğu altın kuralı andırmaktadır. Ülkeler bu kuralların etkin bir şekilde işlemesini sağlamak adına kuralları aşındırmaya yarayan yaratıcı muhasebe ve diğer şeffaf olmayan muhasebe uygulamaları için önlemler almışlardır. Üçüncü dalga ise Yeni Zelanda'nın 1994 tarihli Mali Sorumluluk Yasası ile başlayan enflasyon hedeflemesi ile diğer gelişmiş ve gelişmekte olan ülkelerin mali kuralları yürürlüğe koymaya başlamasıyla sürmektedir. Bu kurallar, çeşitli devletlerin bir dizi dengeli bütçe yükümlülükleri, borçlanma limitleri ve harcama limitleri olarak karşımıza çıkmaktadır. Önceki kural dalgalarının aksine üçüncü dalganın ortak bir paydası muhasebe standartları, düzenli raporlama ve orta vadeli bütçe çerçevesinin önemli kurumsal faktörler olarak belirlenmesidir (Kopits, 2001).

\section{B. Mali Kuralların Teorik Çerçevesi}

Mali kural en genel tanımılla bütçe dengesi, borçlanma, harcama veya vergilemeye yönelik olarak mali göstergeler üzerine limit koyan, yasal veya anayasal zeminde düzenlenen maliye politikalarıdır. Mali kurallara ilişkin çeşitli tanımlamalar yapılmakla beraber tüm bu tanımların altında yatan ana fikir, maliye politikasına yasal bir sınır getirilerek hükümetlerin bu yönde hareket etmelerini sağlayan bir kısıtlamadır (Günaydın ve Eser, 2009: 55).

Debrun (2008: 8)'a göre mali kurallar dört geniş kategoriye ayrılmak mümkündür:

i) Denk bütçe, altın kural, açık sınırlamaları,

ii) Brüt veya net kamu borç oranına getirilen sınırlamalar,

iii) Toplam harcamalara veya belirli harcama kategorilerine getirilen harcama tavanlar1,

iv) Genel vergi yüküne bir sınır getirmek veya dönem öncesinde beklenmeyen gelir fazlalıklarının tahsisine yönelik kurallar.

Gelişmiş ülkelerde harcama baskıları, bütçe harcamaları içerisindeki katı nitelikte harcamaların payının artması ve demografik yapıdaki değişim ülke sosyal güvenlik sistemlerini olumsuz yönde etkilemiştir. Bu durum, gelecekte ortaya çıkması muhtemel ihtiyaçların temin edilmesinde ilave bir mali alanın yaratılması ihtiyacını doğurmuş ve bu ilave mali alanın oluşturulmasında mali kuralların etkili olabileceği düşünülmüştür (Kaya, 2009: 17-18).

$\mathrm{Bu}$ nedenlerle mali kuralların uygulanmasının bazı teknik gerekçeleri vardır. Bunlar Aktan (2011: 5-6; Özker ve Biniş, 2009)'a göre şöyledir:

Mali disiplini sağlamak, Makroekonomik istikrarı sağlamak, Mali sürdürebilirliği sağlamak, Hükümetin kredibilitesinin arttırmak, Siyasi popülizmi engellemek, Diğer finansal politikaları desteklemek, Negatif dışsallıklara karşı önlem almak şeklinde sıralanabilir. 
Mali kuralların çoğu en az bir ortak özelliği paylaşmaktadır. Bu ortak özellik, ihtiyari maliye politikalarını ortadan kaldırmak ve böylelikle makroekonomik politikaların uygulanmasında güvenilirliğin sağlanmasıdır. Ancak altı çizilmelidir ki kısa vadede güvenilirlik inşa etme adına önemli bir adım olan mali kurallar ancak uzun vadede güvenilir olabilir. Ayrıca tasarlanan çoğu mali kural olası dışsal şoklara karşı esneklik sağlayacak sapma hükümlerine yer vermektedir. Belirlenen hedefin altında ve üstünde dalgalanabilecek marj oranları, alternatif acil fonun işletilmesi ya da uluslararası bir kriz, ulusal felaket gibi durumlarda takdire bağlı maliye politikasının uygulanması bu durumun örnekleridir (Kopits, 2001).

Mevcut maliye politikası kuralları hem tasarlanma hem de uygulama açısından ülkeden ülkeye farklılık göstermektedir. Avustralya, Kanada, Yeni Zelanda, Birleşik Krallık gibi Anglo-Sakson ülkeler şeffaflığa önem vermektedir. Avrupa Parasal Birliği, İstikrar ve Büyüme Paktı ve İsviçre'yi kapsayan Kıta Avrupası ülkeleri ile Arjantin, Brezilya, Kolombiya, Peru ve Hindistan gibi yükselen piyasa ekonomileri sayısal referanslara önem vermektedirler (Kopits, 2001). Genel olarak denilebilir ki mali kuralların tasarlanmasında ve uygulamasında gelişmiş ülkeler, var olan mali istikrarın muhafaza edilmesini hedeflerken gelişmekte olan ülkeler açısından daha önem arz eden şey güvenilirliğin sağlanmasıdır (Tepav, 2010).

Hedef olarak belirlenen kuralların yaptırımı olmaması hükümetlerin, bu kurallardan kolay bir biçimde vazgeçmesini mümkün kılabilmektedir. Özellikle konjonktürün dalgalanma dönemlerinde hükümetler, herhangi bir yaptırımın olmaması nedeniyle kuralları istedikleri gibi esneterek mali disiplini sağlama adına getirilen mali kuralları etkinsiz hale getirebilmektedirler (Günaydın ve Eser, 2009: 58). Zira mali kurallar, hükümetlerin uygulayacağı maliye politikalarının kredibilitesini arttırmak, mali konsolidasyonu hedefleyerek mali disiplin ve mali performansı güçlendirmeye katkı sağlamak için tasarlanmakta ve uygulanmaktadır (Karakurt ve Akdemir, 2010a: 230; Karakurt ve Akdemir, 2010b). Bu nedenlerledir ki mali kurallar daha tasarlanma aşamasındayken izleme, denetim ve yaptırım aşamalarının üzerinde sıklıkla durulmaktadır.

Özetlemek gerekirse (Kopits and Symanski, 1998: 6)'e göre, mali kuralların temel özellikleri:

i. Mali kulların tanımı net bir şekilde yapılmalı ve belirsizliğe asla yer verilmemeli,

ii. Mali kuralın uygulanma aşamasında şeffaflığa özen gösterilmeli,

iii. Mali kurallar basit ve anlaşılır düzeyde olmalı,

iv. Mali kurallar dışsal şoklara karşı esnek olmalı, hareket sahası bırakmalı,

v. Mali kurallar amaçlanan sonuçlarla uyum göstermeli,

vi. Mali kurallara yeterli kredibilite sağlanmalı,

vii. Mali kurallar uygulanan diğer politikalarla koordineli olmalı,

viii. Mali kurallar yapısal anlamda uygulanan reformları destekler biçimde tasarlanmalidir. 
Mali kuralların tarihsel, felsefi ve teorik temelleri inceledikten sonra sosyal güvenlikle ilgili olarak $\mathrm{AB}$ ülkelerinin uyguladıkları mali kural örnekleri incelenecektir.

\section{Sosyal Güvenlikle İlgili Mali Kurallar: Ülke Örnekleri}

Mali kurallar tartış1lırken genellikle sosyal güvenlik kurumlarına yönelik mali kurallar ihmal edilmekte veya yeterli ölçüde dikkate alınmamaktadır. Günümüzde, dünyada çoğu sosyal güvenlik sistemleri, yüksek mali yük altında iken düşük koruma sağlamakta ve finansal kriz içindedir. Dolayısıyla, sosyal güvenlik sistemlerinin sürdürülebilirliği ciddi tehdit altındadır (Muter, Gökbunar, 1998). Bu bağlamda, son yıllarda gerek gelişmiş ve gelişmekte olan ülkelerde gerekse de Türkiye'de sosyal güvenlik açıkları büyük sorun haline gelmeye başlamıştır. Özellikle sosyal güvenlik açıkları bütçe dengesi ve kamu borç stoku gibi mali yapının temel yapı taşlarını olumsuz yönde etkilemektedir. $\mathrm{Bu}$ kapsamda Türk Sosyal Güvenlik Sistemi için mali kural önerisine geçmeden önce bazı ülkelerin sosyal güvenlikle ilgili mali kural uygulamaları incelenecektir. İncelenen ülkeler AB ülkeleri olmakla beraber her ülkenin farklı yıl ve şekillerde uyguladığı mali kurallar Tablo 4'de gösterilmiştir.

Tablo 4'e göre $\mathrm{AB}$ ülkeleri üzerine yapılan sosyal güvenliğe ilişkin mali kuralların geçmişine bakıldığında 1992 yılına kadar dayanan bir süreç gözlemlenmektedir. Kural tipinde görüleceği üzere bütçe dengesi, gelir ve harcama olmak üzere farklı kurallar tasarlamış ve uygulamışlardır. Bazı ülkeler yalnızca sosyal güvenliğe yönelik mali kural uygularken bazıları merkezi hükümet ve yerel yönetimlerle birlikte daha kapsamlı bir mali kural uygulamasına gitmişlerdir. Kurallarla hedeflenen veya kısitlanmak istenenler yine ülkeden ülkeye farklılık göstermektedir. Bazı ülkeler harcamalar üzerinde dururken diğerleri sosyal güvenlik harcaması ve bütçe dengesine odaklanmışlardır. Kuralların uygulanacağı zaman dilimi ise çoğu ülkede çok yıllı iken, nadiren yıllık ve konjonktür dönemleri tercih edilmiştir. Hukuki zemin olarak, yasalar, anayasalar, üst düzey normlar ve koalisyon anlaşmaları gibi çeşitli yasal temellerde mali kurallar somutlaştırılmıştır. Mali kuralların izlenmesi ve denetlenmesi aşamalarında ise Maliye Bakanlığı, Ulusal Parlamento, Sayıştay, Hükümet ve Bağımsız Mali Kuruluşların rol aldığı, aynı zamanda bu kurumların ülkeden ülkeye değişen nitelikte hedeflerin tutmaması durumunda sorumlu tutulacağı gözlemlenmektedir.

Tablo 4'den anlaşılacağı üzere ülkeler, hedeflenen mali kuraldan olası sapmalar veya uyumsuzluklar durumunda bazı eylemler tanımlamışlardır. Ülkeler eylem planı olarak önceden tanımlanmış veya tanımlanmamış otomatik düzeltme mekanizmaları, etkili ve uygun önlemler alma yükümlülüğ̈̈ belirlemişlerdir. Bazı 


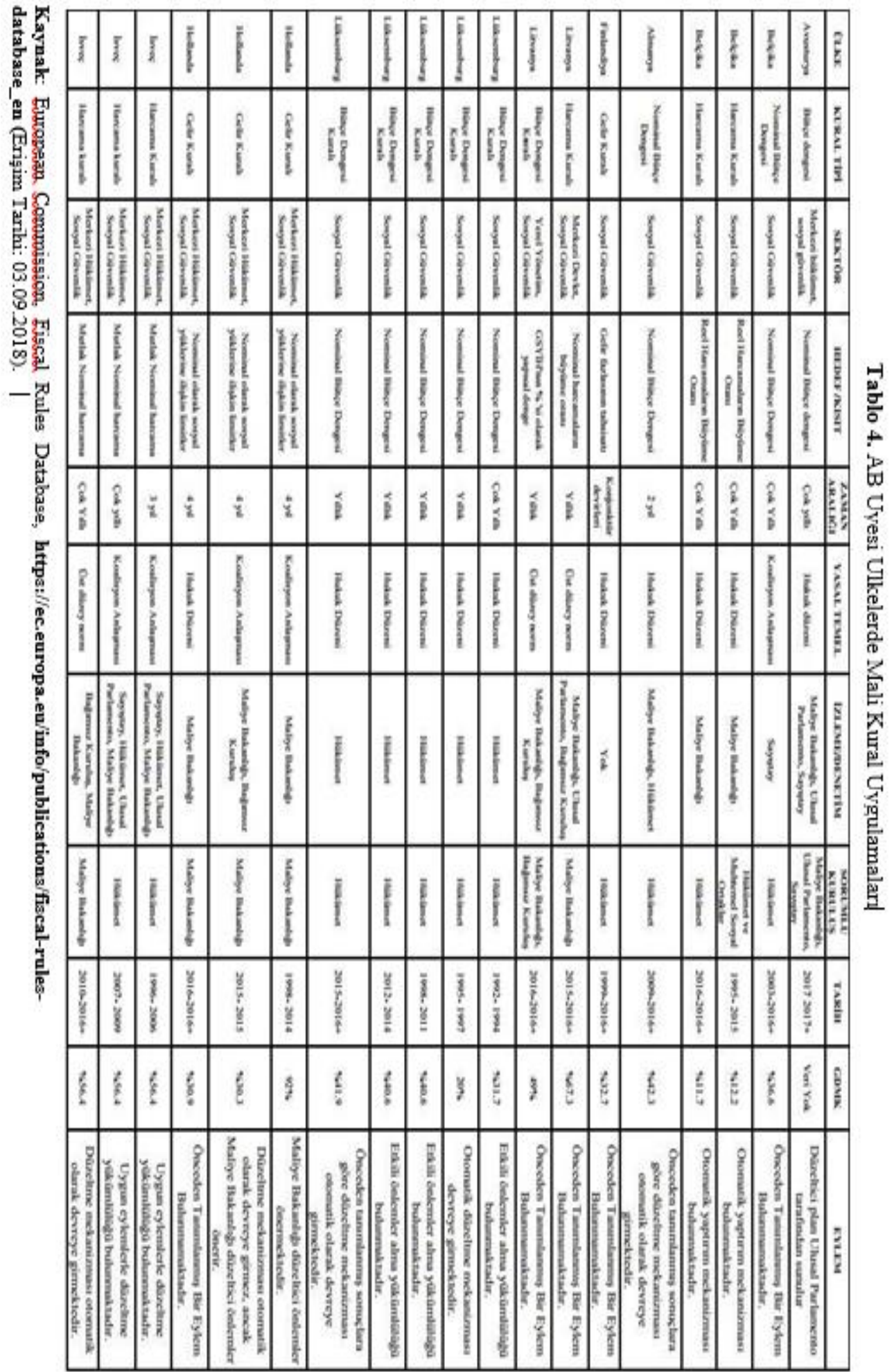


ülkelerde ise önceden tanımlanmış bir eylem yoktur. Ancak bu herhangi bir müdahalede bulunulmayacağ boşluk bırakılmasının sebepleri, izleme, denetim ve sorumluluk gibi görevlerin yüklenildiği kuruluşların takdirine bırakılarak bir nevi uygulanan mali kurala esneklik kazandırmaya çalışmakla ilgilidir.

AB ülkelerinin sosyal güvenlikle ilgili mali kural örnekleri sunulduktan ve açıklandıktan sonra üzerinde duracağımı konu ülkemizde böyle bir uygulamanın yapılıp yapılamayacağıdır. Bu durumu tartışmadan önce üzerinde durulması gereken ise sosyal güvenlik ile mali kural arasındaki ilişkinin kurulması ve Türkiye'deki mali kural tecrübesine kısaca göz atmaktır.

\section{TÜRK SOSYAL GÜVENLİK SISTEMİ VE ULUSAL MALİ SISSTEMIN SÜRDÜRÜLEBİLIRLİĞİ ICÇIN MALİ KURAL ÖNERİSI}

Sosyal güvenlik sistemlerinin en temel özelliklerinden birisi, kapsadığ nüfus yapısına göre yapılan harcama ve yardımların mahiyeti ve iktisadi kaynaklar arasında sıkı bir dengenin kurulmasıdır. Dolayısıyla sosyal güvenlik kurumlarının mali açıdan ihtiyaçlarının bir kereye mahsus biçimde sağlanması yeterli olmayıp, kaynakların sürekliliğinin koruma altına alınması ve bu kaynakların etkin bir şekilde değerlendirilmesi gerekmektedir. Böylelikle oluşturulan sağlam mali yap1, sosyal güvenlik sisteminden beklenen hizmetlerin sağlıklı bir şekilde verilmesini sağlayacaktır (Yurdadoğ, 2000: 86-87).

Mali kuralların temel amacı mali sürdürülebilirliği ve mali disiplini sağlamaya yöneliktir. Bu nedenle mali kurallar, kuralın uygulanacağı ülkenin özel şartları, ihtiyaçları, beklentileri dikkate alınarak tasarlanmaları ve uygulanmaları halinde başarılı olabilirler (Yurdadoğ ve Turan, 2017b: 459-460).

$\mathrm{Bu}$ nedenle Türk Sosyal Güvenlik Sistemine yönelik mali kural uygulaması mali sürdürülebilirliği ve mali disiplini sağlamak adına önemli bir iyileştirebilme potansiyeli taşımaktadır. $A B$ ülkelerinin sosyal güvenlik sistemlerine yönelik olarak uyguladıkları mali kural örneklerinden hareketle Türk Sosyal Güvenlik Sistemi için de bir mali kural uygulanması kanaatini taşımaktayız. AB ülkelerine benzer şekilde kural tipi, hedef, zaman aralığı, yasal temel, izleme ve denetim ile son olarak kuraldan sorumlu olacak kuruluşu ve kurala uyumsuzluk durumunda eylem planını tayin eden öneri Tablo 5'de sunulmuştur.

Türk Sosyal Güvenlik Sisteminin en büyük sorunu açıkların bir türlü kontrol altına alınamamasıdır. Bu açıkların yukarıda sunulduğu üzere birden çok sebebi vardır. Ancak bu kuralı önerirken özellikle dikkate aldığımız bazı sorunlar vardır. Örneğin kayıt dışı sektör, aktif/pasif oranının düşüklüğü, emekli aylıklarının harcama kalemi içerisindeki yüksek payı, fonların etkin değerlendirilmemesi, SGK'nın politik müdahalelere maruz kalması ve sağlık harcamalarının aşırı artışı gibi. Bu nedenler SGK'nın harcama kalemlerinin arttırmasının yanı sıra aynı zamanda gelirlerinin artmasına da engel olmaktadır. Önerilen mali kural çerçevesi bu sorunları tamamen ortadan kaldırmayı kesinlikle sağlamayacaktır. Ancak yapısal anlamda sorunları olabildiğince azaltma ve yapısal reformların gerçekleştirilmesi adına iyi bir başlangıç sağlayacaktır. 
Böylelikle önerilen mali kural çerçevesi birbirine sıkı sıkıya bağlı bu sorunların giderilmesinde önemli bir rol oynayacaktır.

Tablo 5. Türk Sosyal Güvenlik Sistemi İçin Mali Kural Önerisi

\begin{tabular}{|c|c|c|c|c|c|c|c|}
\hline Kural Tipi & Sektör & Hedef / Kisit & $\begin{array}{l}\text { Zaman } \\
\text { Aralı̆̆ı }\end{array}$ & $\begin{array}{l}\text { Yasal } \\
\text { Temel }\end{array}$ & İzleme / Denetim & $\begin{array}{l}\text { Sorumlu } \\
\text { Kuruluș }\end{array}$ & $\begin{array}{l}\text { Kurala Uyumsuzluk Durumunda Eylem } \\
\text { Planı }\end{array}$ \\
\hline $\begin{array}{l}\text { Bütçe Dengesi } \\
\text { Kurali }\end{array}$ & $\begin{array}{l}\text { Sosyal } \\
\text { Güvenlik }\end{array}$ & $\begin{array}{c}\text { Nominal } \\
\text { Bütçe } \\
\text { Dengesi }\end{array}$ & 3 Yillik & $\begin{array}{l}\text { Hukuk } \\
\text { Düzeni }\end{array}$ & $\begin{array}{c}\text { Bağmmsız Mali } \\
\text { Kunuluş, Sayıştay }\end{array}$ & $\begin{array}{c}\text { Sosyal } \\
\text { Güvenlik } \\
\text { Kurumu }\end{array}$ & $\begin{array}{c}\text { İzleme ve Denetimden sorumlu olan Bağımsız } \\
\text { Mali Kuruluş ve Sayıștay tavsiyede bulunur. } \\
\text { (Ekonomik kriz, dis şok afet vb. durumlarda } \\
\text { esneme payı brakilmalıdır.) }\end{array}$ \\
\hline Harcama Kuralı & $\begin{array}{l}\text { Sosyal } \\
\text { Güvenlik }\end{array}$ & $\begin{array}{c}\text { Mutlak } \\
\text { Nominal } \\
\text { Harcama }\end{array}$ & 3 Yillik & $\begin{array}{l}\text { Hukuk } \\
\text { Düzeni }\end{array}$ & $\begin{array}{c}\text { Bağmmsız Mali } \\
\text { Kunuluş, Sayıştay }\end{array}$ & $\begin{array}{c}\text { Sosyal } \\
\text { Güvenlik } \\
\text { Kurumu }\end{array}$ & $\begin{array}{c}\text { İleme ve Denetimden sorumlu olan Bağmsız } \\
\text { Mali Kuruluş ve Sayıstay tavsiyede bulunur. } \\
\text { (Ekonomik kriz, diş şoklar, afet vb. durumlarda } \\
\text { esneme payı brrakilmalidır.) }\end{array}$ \\
\hline
\end{tabular}

Kaynak: Yazarlar tarafindan oluşturulmuştur.

Öncelikle orta vadede açıkları kontrol altına alma adına harcama ve bütçe dengesi kuralı üzerine odaklanılması gerekmektedir. Hedef ya da kısıt alanında ise sayısal bir mali kural önerisi olarak GSYIH'nın yüzdesi veya sosyal güvenlik kurumlarının gelir veya harcamaları üzerinden koyulacak bir oran anlamlı ve etkili olacaktır. Kuralın Orta Vadeli Program ile uyumlu olarak 3 Yillık olarak hazırlanmasının sistemimiz açısından daha uyumlu olacağı düşünülmektedir.

Uygulanacak kuralın yasal temeli olarak "hukuk düzeni" çerçevesinde kastedilen Anayasa/kanun/ya da Cumhurbaşkanlığı Kararnamesi olup aslında Anayasa'da düzenlenmesi kuralın etkinliğini arttıracak bir faktördür. Ancak özellikle yukarıda sıklıkla bahsi geçen Anayasa'nın 65. Maddesinin farklı yorumlanması gibi derin anlaşmazlıkların olması kuralın itibarına zarar vereceğinden yasal temelde birbirleriyle uyumlu hale getirilmiş biçimde hazırlanması daha uygun görünmektedir. Kanaatimizce hali hazırdaki kanunlara bir ekleme olarak değil de sosyal güvenlikle ilgili yeni bir mali kural kanunu veya Cumhurbaşkanlığı Kararnamesi ile düzenlenirse anlaşılması ve denetlenmesi daha uygun olacaktır. Ayrıca bu düzenleme ile birlikte Anayasa'nın 65. Maddesinin sosyal güvenlik sistemiyle ilgili yeni mali kuralla ilgili düzenlemelerin etkinliğini artıracak biçimde yeniden düzenlenmesi olumlu olacaktır.

Uygulanacak mali kuralın izleme ve denetim aşamalarında ise çoğulcu bir yaklaşım faydalı ve anlamlı olacaktır. Sayış̧ay'ın hukuki denetim, yeni kurulmasını önerdiğimiz bağımsız mali kuruluşun ise hukuki ve etkinlik düzeylerinde denetimde bulunması yerinde olacaktır. Son olarak kurala uyulmaması durumunda sorumlu kuruluş SGK'nın kendisi olmalıdır. Siyasi hükümetlerin politik müdahaleleri karşısında yeni tesis edilecek kanunu gerekçe gösterecek olan SGK'ya bu konuda hareket sahası yaratılacaktır. Aynı zamanda kurum kanunlarında idari ve mali açıdan özerk olduğu fakat uygulamada söz konusu olmayan kanuna işlerlik kazandırarak sorumluluğun tamamen kuruma devredilmesini önermekteyiz. Ancak istenilen idari ve mali açıdan özerklik sağlanmayacaksa bu durumda kuralın etkinliği azalacağından kuraldan Hazine ve Maliye Bakanlığı sorumlu tutulabilir.

Tasarlanan mali kurula uyumsuzluk veya hedeften sapma durumunda izleme ve denetimden sorumlu olan Bağımsız Mali Kurul ve Sayıştay tavsiye 
kararında bulunmalıdır. Ancak bu tavsiye kararlarına ek olarak Bağımsız kuruluşun politik müdahalelerden uzak olması nedeniyle bu kuruluşun mali açıdan öneride bulunduğu kararlar kesin olmalı ve SGK tarafindan bu önerilere zorunlu olarak uyulmalıdır. Böylelikle önerilen mali kurala, kurulması önerilen kuruluşun bağımsızlık ve yaptırım gücü nedeniyle etkinlik kazandırılmış olunacak ve başarı şansı artacaktır. Ancak altı çizilmelidir ki kurala uyulmaması durumunda sorumlu olan SGK'ya ya da Hazine ve Maliye Bakanlı̆̆ı'na muhakkak bir cezai müeyyidede (Örneğin gider oluşturucu eylemlerin askıya alınması ya da kuralı aşan yöneticilerine idari para cezası) bulunulmalıdır. Ayrıca olası ekonomik kriz, dış şok, doğal afet vb. durumlarda kurala esneklik kazandırılması adına sapma payı bırakılmalıdır.

Sosyal Güvenlik sistemi için önerilen mali kural çerçevesi alınacak mali kararların etkinliğini ve güvenilirliğini artıracaktır. Zira iradi olarak alınan mali kararların olumsuz etkileri bertaraf edilecektir. Bu olumlu etkilere paralel olarak aynı zamanda politikacıların popülist yaklaşımları sebebiyle aşırı harcama, bütçe açığı ve borç yükünün artması gibi mali kırılganlıkların azaltılması sağlanacaktır. Ancak belirtilmelidir ki önerilen mali kural çerçevesi en nihayetinde kalıcı ve kökten bir çözüm olarak algılanmamalıdır. Ama yine de kuralın çerçevesi ve aşağıda belirtilecek olan kurumsal düzenlemelerle beraber düşünüldügünde Türk Sosyal Güvenlik Sistemi adına önemli bir gelişimin sağlanmasına katkı sunacaktır.

Mali kuralların etkinlik kazanması ve başarılı olması için bazı tali faktörlerin güçlülüğü de önem arz etmektedir. Önerilen mali kuralın yanında aşağıda bahsi geçen kurumsal düzenlemelerin yapılması veya yapılmaması kuralın başarısını etkileyen bir faktör olacaktır.

\section{VI. ÖNERİLEN MALİ KURALIN ETKİNLİĞİ İÇİN KURUMSAL ALTYAPININ GÜÇLENDİRILMESINE YÖNELIKK ÖNERILER}

Mali kurallara ilişkin yapılan araştırmalar kuralların etkili ve etkin olabilmesi bazı ön koşulların varlığının önemi üzerinde durmaktadırlar. Bunlardan ilki yeterli seviyede mali yönetim alt yapısına sahip olmaktır. Detaylı bilgi ve veri sağlayan güvenilir muhasebe sistemi, temel bütçe kalemlerini gerçekçi bir şekilde tahmin edebilme yeteneği, kapsamlı ve düzenli bütçe raporlama ve kapsamlı iç ve diş denetim mali yönetimin alt yapısını oluşturmaktadır. İkinci olarak kapsamlı reformları gerçekleştirerek mali disiplini sağlamayı amaçlayan siyasal iradenin kararlı bir yapıda olmasıdır. Üçüncü ve son unsur ise mali kuralın yapısı, izlenmesi, değerlendirilmesi ve yaptırımlarla ilgi düzenlemelerle ilgilidir. Mali kuralın yalnızca çıpa işlevi görmesi beklentisi söz konusuysa yukarıda ifade edilen unsurların yanı sıra hangi değişkenler üzerine getirildiği, nasıl bir kısıtlamada bulunduğu, nasıl izlenmesi gerektiği ve hangi yaptırımlarla caydırıcılığı sağlayarak güçlendirileceği oldukça önem arz etmektedir (Tepav, 2010; Ergen, 2013: 99-100).

Türkiye ekseninde mali kurala bakıldığında kalitesiz bir mali intibakın varlı̆̆ mali kural için problem oluşturmaktadır. Zira mali disiplin doğrudan harcama disiplini ilgilidir. Bu nedenle hem gelir hem de gider yönlü kuralların 
eşanlı olarak uygulanması gerekmektedir. Ayrıca muhasebe sistemindeki eksiklikler mali kuralın gerektirdiği programlar arası önceliklerin belirlenmesini zorlaştıracağından muhasebe sistemindeki eksiklikler giderilmelidir. Bu noktada bir diğer vurgulanması gereken ise kamu hesaplarının şeffaflığının sağlanmasıdır. Ayrica belirlenen orta vadeli harcama programı uygulanmaz ise yine mali kural başarısız olacaktır. Son olarak mali kuralın gücü kuralların uyumunu izleyen otorite ile yakından ilgilidir. Türkiye'de TBMM adına denetim yapan Sayıştay, bu izleme ve denetim amaçları için uygun değildir (Tepav,2010). Bu nedenle çoğu ülkede uygulama sahası bulunan bağımsız mali kuruluşlar kurulmalıdır. Sayıştay hukuki denetimi yaparken bağımsız mali kuruluş mali ve etkinlik denetimi yapmalıdır.

Yönetişim ilkelerinden özellikle hesap verilebilirlik ve mali saydamlık, maliye politikalarının kullanımındaki keyfi kararları minimize etmekle beraber kamu mali yönetimine ilişkin göstergelerin de güvenilirliğini arttırmaktadır. Ayrıca bağlayıcı mali taahhütlerin uygulanması, Hazine ve Maliye Bakanının diğer harcamacı bakanlar karşısında delegasyon gücünün arttırılması, bağımsız mali kuruluşların maliye politikası konusunda hükümetlere tavsiyelerde bulunması ve maliye politikası sonuçlarına ilişkin değerlendirmelerde bulunması mali kuralların gücünü arttıracaktır (Ünlükaplan, Yurdadoğ ve Canıkalp, 2017: 245-246). Bu faktörlerin dikkate alınarak uygulanması Türk Sosyal Güvenlik Sistemi için önerilen mali kuralın etkinliğini arttıracaktır.

Ancak mali saydamlık ve hesap verilebilirlik noktasında Sayıştay tarafindan hazırlanan 2012, 2013, 2014, 2015, 2016, 2017 yılı denetim raporlarının denetim görüşü kısmında SGK'nın sunduğu idari faaliyet raporlarının güvenilir ve doğru bilgi içermediği sonucuna varılmıştır (Sayıștay, 2012-2017). Bununla beraber 4 Sayılı Cumhurbaşkanlığı Kararnamesi ile SGK'nın Sayıştay denetiminden çıkarıldığına yönelik bir zemin oluşturulmuştur. Ancak gerek Anayasal düzeyde gerekse de Sayıştay ve 5018 sayılı KMYKK' da hala Sayıştay denetiminin gerçekleşmesi yönünde maddeler bulunmaktadır.

$\mathrm{Bu}$ noktada altı çizilmesi gereken şudur ki, 5018 sayılı KMYKK'nın içeriğinin gereği gibi uygulanması, saydamlık, hesap verilebilirlik ve etkin devlet gibi birçok önemli faktörün sorun olmaktan çıkarılması (Akça, Ünlükaplan ve Yurdadoğ, 2016: 224) neticesinde mali kurallara etkinlik kazandırılacağı rahatlıkla söylenebilir. Ayrıca 5018 sayılı kanunun 14.maddesinde belirtildiği üzere sosyal güvenlikle ile ilgili yapılan düzenlemelerin en az yirmi yıllık aktüeryal denge göz önüne alınarak yapılmasına yönelik örtük kural geliştirilmelidir. Bahsi geçen en az yirmi yıllık perspektif en az elli yıllık olarak tasarlanmalıdır. Böylelikle sistem üzerinde kısa ve orta vadeli müdahalelerin önüne geçilmekle beraber uzun vadeli bir vizyon sağlanarak olası mali yükler minimize edilebilecektir. $\mathrm{Bu}$ düzenlemelerin aksine söz konusu olumsuz ve belirsiz durumların devamı durumunda mali kuralların başarılı olmasını beklemek mümkün değildir.

Sosyal güvenlik sistemimizin en büyük kurumsal altyapı sorunlarından birinin giderilmemesinin nedenlerinden birisi de denetim eksikliğidir. Etkin ve verimli bir denetim sistemi olması halinde, gelirlerin arttırılması ile giderler de 
kontrol edilebilir. Yetersiz denetimler sebebiyle sosyal güvenlik açıları büyümüştür ve büyümeye devam etmektedir. Örneğin 2008-2012 yıllarını kapsayan Manisa ilindeki denetimin sağladığı faydalar Demir ve Canbay'ın 2013 tarihli çalışmasında görülebilir. Bu noktada Sosyal Güvenlik Denetmenlerinin riskli sektörlerin tespitini sağlayarak denetimleri bu alanda yoğunlaştırılmalı ve yapılan denetimlerin etkinliğinin ölçülmesini sağlayacak projeler geliştirilmesi gerekmektedir. Denetimlerin cezalandırıcı olmaktan ziyade yol gösterici ve önlemeye yönelik olması gerekmektedir (Kalkınma Bakanlığı, 2014: 38).

Kurumsal ve yasal altyapıdaki sorunlardan bir diğeri de özerklik kavramıdır. Türk Sosyal Güvenlik Sisteminin etkin bir şekilde işlemesi için kurum kanununda belirtilen ancak uygulanmayan özerklik kavramı öne çıkarılarak mali ve idari açıdan özerklik sağlanmalıdır. Zira özerk bir yapıya sahip olan kurumlara politik müdahaleler azalacağından sistemin dengeli bir yapıy1 yakalamasını kolaylaştıracaktır (Güneş ve Yakar, 2004: 140; Demir, 2015: 187188). Nitekim bu konu hakkında Uluslararası Çalışma Örgütü'nün (ILO), sosyal güvenliğe biçtiği rol oldukça önemlidir. ILO'ya göre etkin bir şekilde yönetilen sosyal güvenlik sistemi, büyüme ve kalkınmanın sağlanmasında etkili olabilir. Ayrıca ILO, sosyal güvenlik kurumlarının yönetiminde baskın olan devletin yerine paydaşlara (sosyal taraflara) doğru açılımın yani bir nevi özerkliğin sağlanmasını önermektedir (ILO, 2001).

Bir diğer kurumsal sorun ise sosyal güvenlik harcamalarının artması yönünde etkide bulunan yapılanma ve planlamada eksikler nedeniyle ortaya çıkan israflardır. Şöyle ki sağlık harcamalarının çok büyük bir bölümü hastane hizmetleri harcamalarına tahsis edilmektedir. Bu yüksek oran, birinci basamak hizmetlerinin zayıf kaldığı dolayısıyla bireylerin ikinci veya üçüncü basamak hizmet veren hastanelere başvurmaları sevk zincirini bozmakta, kaynak israfi ve verimsizlik yaratmaktadır. Bu olumsuz durumla ilgili olarak gerekli düzenlemeler yapıldığg takdirde daha etkin ve daha ekonomik sağlık hizmeti sunularak harcamalar kontrol altına alınabilir. Diğer bir nokta ise son yıllarda artan koruyucu sağlık hizmetleri hakkında neredeyse tek başına hizmet veren Sağlık Bakanlığının bütçesi içinde koruyucu sağlık hizmetleri için gerekli bütçe tahsis edilmemesi ve ihmal edilmesidir. Oysa koruyucu sağlık hizmetlerinin arttırılması olası hastalıkların negatif etkilerini önleme adına önem arz etmekte ve daha etkin bir yöntem olarak bilinmektedir. Ayrıca ilaç ve tıbbi malzeme konusu ve yıllar içindeki gelişimi incelendiğinde yeniden düzenlenmesi, sosyal güvelik sisteminden yapılan ödemelerin yani harcamaların kontrol altına alınması adına önem arz etmektedir (Yurdadoğ, 2007: 608).

\section{SONUÇ}

Son dönemlerde gerek dünyada gerekse ülkemizdeki en büyük problemlerden biri Sosyal Güvenlik Sistemlerinin sürdürülemez mali yapısıdır. Türk Sosyal Güvenlik Sistemi üzerine odaklanılan bu çalışmada yasal düzenlemeler ve mali durum üzerine değerlendirmeler sunulmuştur. Yasal zeminde Anayasanın 65. Maddesi ile ilgili yorumlar sunulmuş ve bu yorumlar neticesinde söz konusu maddenin üzerinde uzlaşmanın olmadığı sonucuna 
varılmıştır. Bu noktada dikkate alınması gereken asıl yorumun AYM'nin bir kararında geçen: "devlete düşen görev, sosyal güvenlik kurumlarının gücünün zayıflamasına neden olabilecek düzenlemelerden kaçınmaktır" ilkesi olacağ 1 sonucuna varılmıştır.

Türk Sosyal Güvenlik Sisteminin açıklarının nedenleri ve etkileri üzerinde durulan ikinci bölümünde ise literatürde konu üzerine çalışma yapan araştırmacıların görüşleri gelir, gider, yapısal, politik ve sosyal kaynaklı olmak üzere sınıflandırılarak sunulmuştur. Genel olarak sistemin; Aktif/pasif oranının düşüklüğü, kayıt dış1 ekonomi, işgücüne katılım oranın düşüklüğü, erken emeklilik uygulamaları, fonların verimli ve etkin kullanılmaması, norm ve standart birliğinin olmaması, prim oranlarının yüksekliği, gelir düzeyindeki düşüklükler, prim tahsilatında yaşanan sorunlar, sosyal güvenlik ahlakının yoksunluğu, sağlik sektöründeki ihmaller, yanlış finansman yöntemlerinin uygulanması, kurumun özerkliğinin olmaması, kurumun politik müdahalelere maruz kalması, demografik yapıdaki değişim, prim afları gibi nedenlerle açık verdiği tespit edilmiştir.

Sosyal Güvenlik sisteminin verdiği açıkların bütçe transferleri yolu ile finanse edilmesinin de bazı olumsuz sonuçlar yarattığı tespit edilmiştir: Devlet bütçesindeki açık seviyesini ve kamu kesimi borçlanma gereksinimini arttırması, borçlanmanın finansman yapısına göre gelir dağılımında bozulmalara ve özel sektör yatırımlarını dışlamaya neden olduğu vurgulanmıştır.

$\mathrm{AB}$ ülkelerinin sosyal güvenlikle ilgili mali kural tecrübesinden hareketle çalışmamızda Türk Sosyal Güvenlik Sistemi için mali kural önerisinde bulunulmuştur. Önerilen mali kuralda hem harcama dengesi hem de bütçe dengesini sağlama adına birbirini tamamlayıcı bir perspektif çizilmiştir. Kuralın Orta Vadeli Programlarla uyumlu olmasının daha uygun olacağı düşüncesiyle 3 yıllık bir perspektifle tasarlanması ve uygulanması öngörülmüsstür. Yasal temelde "hukuk düzeni" çerçevesinde birbirleriyle uyumlu hale getirilmiş biçimde sosyal güvenlikle ilgili yeni bir mali kural kanununun veya Cumhurbaşkanlığ Kararnamesinin düzenlenmesi ve Anayasa'nın 65. Maddesinin sosyal güvenlik sistemiyle ilgili yeni mali kuralla ilgili düzenlemelerin etkinliğini artıracak biçimde yeniden düzenlenmesi olumlu olacaktır. Uygulanacak mali kuralın izlenme ve denetleme kısmında ise üçlü bir saç ayağı planlanmıştır. Sayıştay'ın hukuki denetimin yanında etkinlik denetimi üzerinde durmaması ve mali kuralın başarısının artmasında Bağımsız Mali Kurumların daha çok savunulması nedeniyle kuralın denetimi ve izlenmesi farklı kurumların farklı görev alanları şeklinde tasarlanması ihtiyacını doğurmuştur. Uygulanacak kuralın, hukuki denetiminin Sayıştay tarafından hem etkinlik hem de hukuki denetiminin ise yeni tesis edilecek Bağımsız Mali Kurumun yapacağı şeklinde bir tasarım öngörülmüştür. Kurala uyumsuzluk durumda ise kuralın takipçilerinden olan Bağımsız Mali Kurum ve Sayıştay'ın tavsiye kararı devreye girmektedir. Ancak bu tavsiye kararlarına ek olarak Bağımsız kuruluşun politik müdahalelerden uzak olması nedeniyle bu kuruluşun mali açıdan öneride bulunduğu kararlar kesin olmalı ve SGK tarafindan bu önerilere zorunlu olarak uyulmalıdır. Böylelikle 
önerilen mali kurala, kurulması önerilen kuruluşun bağımsızlık ve yaptırım gücü nedeniyle etkinlik kazandırılmış olunacak ve başarı şansı artacaktır.

Mali kural önerisinin ardından kuralın başarı şansını arttırıcı bazı kurumsal düzenlemelerin yapılması önerilmiştir. Bu kurumsal düzenlemeler 5018 sayılı KMYKK'nda yer alan saydamlık, hesap verilebilirlik, etkinlik gibi iyi yönetişim ilkelerinin tesis edilmesine yöneliktir. Önerilen kurumsal düzenlemelerin yapılması önerilen mali kuralın etkinliğinin ve başarısının artmasına yardımcı olacaktır. Aksi takdire önerilen kuralın başarı şansı zayıflayacaktır. Son olarak belirtilmelidir ki bu mali kuralın başarısı yalnızca sosyal güvenlik sisteminin sürdürülebilirliğine yönelik değil ulusal mali sistemin de sürdürülebilir olmasına katkı sağlayacaktır. Önerilen mali kural çerçevesi en nihayetinde kalıcı ve kökten bir çözüm olarak algılanmamalıdır. Ama yine de önerilmiş olan kural çerçevesi ve kurumsal düzenlemeler bir bütün olarak düşünüldüğünde Türk Sosyal Güvenlik Sistemi adına önemli bir gelişimin sağlanmasına katkı sunacaktır.

\section{KAYNAKÇA}

Akça, H., Ünlükaplan, İ., \& Yurdadoğ, V. (2016). Kayıt Dışı Ekonomi, Yolsuzluk ve Kayıt Dış1 Devlet. Çukurova Üniversitesi İktisadi ve İdari Bilimler Fakültesi Dergisi, 20(2), 211-227.

Aktan, C. C. (2011). Kurumsal Maliye Politikası ve Mali Kurallar, Çimento İşveren Dergisi. 1(25), 4-13.

Algan, B. (2006). Ekonomik, Sosyal ve Kültürel Hakların Korunması, Ankara Üniversitesi Sosyal Bilimler Enstitüsü Yayımlanmamış Doktora Tezi.

Altunöz, U. (2017). Sosyal Güvenlik Politikaları Açısından Bütçe Transferlerinin Makroekonomik Etkileri: Türkiye Deneyimi. International Review of Economics and Management, 5(1), 58-77, doi: 10.18825/iremjournal.286089

Anayasa Mahkemesi (AYM). (1997). 1996/66, 1997/7 Numaral1 Karar http://www.kazanci.com/kho2/ibb/files/amk1994-92.htm (Erişim Tarihi, 18.10.2018).

Bulut, N. (2003). Küreselleşme: Sosyal Devletin Sonu Mu?. Ankara Üniversitesi Hukuk Fakültesi Dergisi, 52(2), 173-197.

Canbay, T. ve Demir M. (2013). Türkiye’ de Sosyal Güvenlik Açıkları ve Sosyal Güvenlik Ahlakı. Yönetim ve Ekonomi Dergisi, 20(2), 303-315.

Cural M. (2015). Türk Sosyal Güvenlik Sistemi'nin Mali Yapısı ve Sisteme Yapılan Bütçe Transferlerinin Ekonomik Yansımaları. Süleyman Demirel Üniversitesi IİBF Dergisi, 21(2), 693-706.

Çelik, A. (2007). Anayasa Mahkemesi Kararı ve Sosyal Güvenliğin Geleceği, http://www.kristalis.org.tr/aa_dokuman/aym_yorum.doc Erişim Tarihi: 29.08.2018.

Çelikyay, H.S. (2011). Yeni Anayasa Tartışmaları ve Sosyal Haklar, Sosyal Haklar Uluslararası Sempozyumu-III.

Debrun, X. Epstein, N. ve Symansky, S. (2008). A New Fiscal Rule: Should Israel 'Go Swiss?', IMF Working Paper, No.87.

Demir, M. (2015). Sosyal Güvenlik Kurumu'nun Özerklik Sorunu, Siyaset, Ekonomi ve Yönetim Araştırmaları Dergisi, 16. Çalışma Ekonomisi ve Endüstri İlişkileri Kongresi Özel Sayısı.

Demir, M. ve Canbay, T. (2013). Türkiye'de Sosyal Güvenlik Açıklarının Azaltılmasında Denetimin Önemi (Manisa İli Örneği). Celal Bayar Üniversitesi Sosyal Bilimler Dergisi, 11(3), 451-467.

Dinler, V. (2008). Devletin İktisadi ve Sosyal Ödevlerinin Sınırı Açısından İdarenin Sorumluluğu. Hitit Üniversitesi Sosyal Bilimler Enstitüsü Dergisi 1(1), 1-19.

Erdoğan, Ç. (2014). Sosyal Güvenlik Hakkının Yargıtay Kararlarına Yansıması. Sosyal Güvenlik Dergisi, 4(2), 193-217. 
Ergen, Z. (2013). Mali Disiplinin Sağlanmasında Mali Kurallar. Finans Politik \& Ekonomik Yorumlar Dergisi, 50(84), 93-108.

Ergün, Y. ve Cura, S. (2016). Anayasal İktisat Yaklaşımı Açısından Avro Krizi. Yönetim ve Ekonomi, 23(1), 263-286, doi: 10.18657/yecbu.51119

Erol, S. I. (2014) Türkiye'de Sosyal Güvenlik Sorunları ve Sosyal Güvenlik Ahlakı. Kamu-ISs Dergisi, 13(3), 37-70.

European Commission Fiscal Rules Database. (2018). https://ec.europa.eu/info/publications/fiscalrules-database_en (Erişim Tarihi, 03.09.2018).

Fırat, M.S. (2016). Türkiye'de Sosyal Güvenlik Kurumu Bütçesi ve Sosyal Güvenlik Açıkları. Türkiye Barolar Birliği Dergisi, 127, 317-338.

Gökbunar, A. R., Alparslan, U. ve Duramaz, S. (2016). Yaşlı Nüfusa Yönelik Sağl1k Harcamalarının Azaltılmasında Kamusal Politikaların Önemi. International Journal of Economic and Social Research, 12(1), 109-122.

Gökbunar, R. (1997), Kamu Finansmanında Demokratikleşme ve Ekonomik Anayasa Önerisi. Şükrü Postacıoğlu'na Armağan, Dokuz Eylül Üniversitesi Hukuk Fakültesi Dergisi.

Gözler, K. (2001). Anayasa Değişikliği Gerekli mi? 1982 Anayasası için Bir Savunma, Bursa: Ekin.

Günaydın, İ. ve Eser, L. Y. (2009), Maliye Politikasındaki Yeni Trend: Mali Kurallar. Maliye Dergisi, 156, 51-65.

Güneş, İ. ve Yakar, S. (2004). Sosyal Sigorta Finansman Yöntemleri ve Türkiye'de Sosyal Sigorta Kurumlarının Finansman Yöntemlerinin Değerlendirilmesi. Çukurova Üniversitesi Sosyal Bilimler Enstitüsü Dergisi, 13(2), 127-142.

IMF (2016). Fiscal Rules Dataset, 1985-2015, International Monetary Fund Fiscal Affairs Department Fiscal Policy and Surveillance Division. https://www.imf.org/external/datamapper/fiscalrules/FADFiscal\%20Rules\%20Dataset.xlsx (Erişim Tarihi, 17.02.2019).

ILO (2001). Social Security: A New Consensus, Geneva: International Labour Office.

Kaboğlu, İÖ. (2010). Anayasada Sosyal Haklar: Alanı ve Sınırları, Sosyal Haklar Sempozyumu 2, Bildiriler, İstanbul: Petrol-İş.

Kalkınma Bakanlığı. (2014). Sosyal Güvenlik Sisteminin Sürdürülebilirliği Özel İhtisas Komisyonu, Hazırlayan: Oğuz Karadeniz, Kalkınma Bakanlığı Onuncu Kalkınma Planı.

Kara, O., Kurutkan, M.N., Çolak, M. (2016). Sosyal Güvenlik Açığının Seçilmiş Makroekonomik Değişkenler ile İlişkisi: ARDL Sınır Testi Yaklaşımı. The Journal of Academic Social Science Studies, 49, 205-224.

Karabulut, A. (2016). Sosyal Güvenlik Hakkı ve 1982 Anayasası'na Yansımaları. İş ve Hayat Dergisi, 3, 187-208.

Karadeniz, Y. ve Vural, T. (2016). İhtiyari Maliye Politikalarına Karşı Mali Kurallar: Teorik Bir Analiz. Maliye Araştırmaları Dergisi, 2(1), 43-60.

Karakurt, B. ve Akdemir, T. (2010a), Kurallı Maliye Politikası: Türkiye'de Kurallı Maliye Politikası Örnekleri. Maliye Dergisi, 158, 226-261.

Karakurt, B. ve Akdemir, T. (2010b), Türkiye'de Mali Kural Uygulamaları: Sayısal Olmayan Kurallardan Sayısal Kurallar Geçiş, Mali Kurallar, Editörler: Coşkun Can Aktan, Ahmet Kesik ve Fatih Kaya, T.C. Maliye Bakanlığı Strateji Geliştirme Başkanlığı, Yayın No: 2010/408, Ankara.

Kaya, F. (2009), Mali Kural Uygulamaları ve Türkiye İncelemesi, Ankara: DPT Uzmanlık Tezi.

Kopits, G. (2001). Fiscal Rules: Useful Policy Framework Or Unnecessary Ornament, IMF Working Papers, No. 01/145, Washington.

Kopits, G. ve Symansky S. (1998). Fiscal Policy Rules, IMF Occasional Papers, No. 162, Washington.

Muter, N.B. ve Gökbunar, R. (1998). Türkiye'de Sosyal Güvenlik Sisteminin Makro Sorunları ve Çözüm Önerileri. Halil Nadaroğlu'na Armağan, Marmara Üniversitesi İ̈BF Dergisi, 14 (1), 271-288.

Özbudun, E. (2014). Türk Anayasa Hukuku, Ankara: Yetkin.

Özker, A.N. Biniş, M. (2009) Mali Kurallar ve Bir Vergi Anayasası Yaklaşımı. Hukuk ve İktisat Araştırmaları Dergisi, 1(1), 17-39. 
Özveri, M. (2011). Türk Hukukunda Sosyal Hakların Dava Yoluyla Gerçekleştirilmesi, Sosyal Haklar Uluslararası Sempozyumu III Bildiriler, Petrol-iş Yayını, İstanbul.

Sağlam F, (2008). Sosyal Devlet İlkesi ve Duyarsızlaşma, Edt. Mehmet UÇUM, Devrim Ulucan'a Armağan, İstanbul: Legal.

Sayıştay Başkanlığı (2012-2017). Sosyal Güvenlik Kurumu 2012, 2013, 2014, 2015, 2016, 2017 Y11 Sayıştay Denetim Raporu.

SGK Aylık İstatistik Bülteni, http://www.sgk.gov.tr/wps/portal/sgk/tr/kurumsal/istatistik/ aylik_istatistik_bilgileri (Erişim Tarihi,18.8.2018).

Sakal, M ve Şahin, E.A. (2009). Anayasal İktisat. Dokuz Eylül Üniversitesi Sosyal Bilimler Enstitüsü Dergisi, 11(1), 69-112.

Tanör, B ve Yüzbaşığlu, N. (2004). 1982 Anayasasına Göre Türk Anayasa Hukuku, İstanbul: Yap1 Kredi.

Tatlı, H. ve Göçer, İ. (2015). Türkiye'de Sosyal Güvenlik Politikalarının Sürdürülebilirliği: Çoklu Yapısal Kırılmalı Eş-bütünleşme Analizi. Business and Economics Research Journal, 6(3), 87-111.

Temiz, Ö. (2014). Türk Hukukunda Bir Temel Hak Olarak Sağlık Hakkı. Ankara Üniversitesi Siyasal Bilimler Fakültesi Dergisi, 69(1), 165-188.

Tepav (2010). Mali Kural Nasıl İşler? Tepav Politika Notu.

Tuncay, A.C. ve Ekmekçi, Ö. (2016) Sosyal Güvenlik Hukuku Dersleri, İstanbul: Beta.

Ünlükaplan, İ., Yurdadoğ, V. ve Akça, H. (2017). Geçiş Ekonomilerinde Maliye Politikası Uygulamalarına Anayasal İktisat Yaklaşımı. Bolu Abant İzzet Baysal Üniversitesi Sosyal Bilimler Enstitüsü Dergisi, 17(1), 67-82.

Ünlükaplan, İ., Yurdadoğ, V. ve Canikalp, E. (2017). Eurasian Economies in Transition "Fiscal Rules, Creative Accounting and Fiscal Transparency: An Evaluation of Transition Economies. Edited by Aysen Hiç Gencer, İlyas Sözen and Selahattin Sarı. Cambridge Scholars Publishing.

Yıldırım, H. (2012). Türkiye'de 2001'den Günümüze Kayıt Dış1 Ekonominin Sosyal Güvenlik Kurumu Açıkları Üzerindeki Etkilerinin İncelenmesi ve Değerlendirilmesi, Gazi Üniversitesi Sosyal Bilimler Enstitüsü Yayımlanmamış Yüksek Lisans Tezi.

Yılmaz, B.E. (2014), Sosyal Güvenlik Ekonomisi: Türkiye'de Sosyal Güvenlik Sisteminin Açıkları, Finansmanı ve Reformu, İstanbul: Derin.

Yurdadoğ, V. (2000). Sosyal Güvenliğin Finansman Yöntemleri. Sosyal Güvenlik Dünyası Dergisi, 2(7-8), 86-93.

Yurdadoğ, V. (2007). Türkiye'de Sağlık Harcamalarının Finansmanı ve Analizi. Çukurova Üniversitesi Sosyal Bilimler Enstitüsü Dergisi, 16(1), 591-610.

Yurdadoğ, V. (2017a). Sosyal Güvenlik ve Yeniden Gelir Dağılımına Etkisinin Teorik Çerçevede Değerlendirilmesi Çukurova Üniversitesi Sosyal Bilimler Enstitüsü Dergisi,26(1),254-269.

Yurdadoğ, V. ve Turan, T. (2017b). Türkiye İçin Neden Bir Harcama Kuralı? 8.Uluslararası Balkanlarda Sosyal Bilimler Kongresi, Köstence, Romanya, 6-11 Eylül, 457-462.

\section{SUMMARY}

In this study, a solution with a fiscal rule perspective has been proposed in order to eliminate the negative effects of the social security deficits on the budget and economy, to bring the social security system to a sustainable level and to enable the system to operate more effectively. The study focuses on the 65th article of the Constitution which is a subject has not been extensively discussed before. Because such an article is substance that some writers see the item in favor of the fiscal balance of the state, while some authors interpret it as a violation of the principle of social state. For this reason, in this study, different points of view have been interpreted in a way that is compatible with the proposed fiscal rule. In the continuation of the study, a different approach has 
been presented in four different categories as income, expense, structural, political and social reasons rather than giving reasons for social security deficits one by one. In addition, the negative effects of the mentioned social security deficits on budget and economy were discussed.

In this study, the historical and theoretical framework of fiscal rules is mentioned before proceeding with the proposal of the fiscal rule for the Turkish Social Security System. Then, the European Union countries have introduced fiscal rule practices regarding social security. When the applications of the European Union countries are examined, it has been observed that since 1992, they have started to implement the fiscal rules related to social security. Generally, there is a framework in which the rule of expenditure and budget balance is focused on, the rule is predetermined in terms of legal basis and supervision, the rules are prepared with a multi-year understanding and finally there are measures to be taken in case of deviation from the rule. Based on this experience of the European Union countries, the fiscal rule framework for the Turkish Social Security System was prepared. According to this framework, it is emphasized that the fiscal rule will be more meaningful both as budget balance and spending rule. Because, a limitation with the spending rule, rather than just a perspective focused on the budget balance, will have more positive results in terms of performance. It was thought that the implementation of the rule for three years would be correct in terms of harmonization with the medium term programme.

Furthermore, it is thought that the rule should be implemented with a new law and not in addition to the current laws, and that the amendment's regulation to cover the fiscal rule of article 65 of the Constitution will increase the effectiveness of the rule. In addition to the Court of Accounts, it has been envisaged to monitor and supervise the rule by the independent financial institution that we proposed to establish a new establishment. Because, considering that the Court of Accounts performs almost entirely legal audit, the independent financial institution to perform the audit of the activity will contribute more to the financial performance. It was considered that taking the deterrent measures such as the suspension of expense-generating actions and the application of administrative fines, if the social security institution is responsible for the rule itself and the rule is not complied with, will provide efficiency and success to the rule. Possible economic crisis, external shock, disaster etc. it is also emphasized that leaving the deviation share to the rule will provide flexibility to the rule. In addition, it was emphasized that making the institutional arrangements to be made in accounting standards, transparency, accountability, efficiency, autonomy, supervision and expenditure programs will bring efficiency and functionality to the fiscal rule.

As a result, it is considered that the proposed fiscal rule framework will provide significant and positive contributions to the Turkish Social Security System in terms of efficiency and sustainability, but this framework is not definitely solution. 